\title{
Introduction. The Pacific on Screens: From Representation to Reappropriation
}

Introduction. Le Pacifique au cinéma : représentations et réappropriations

Jessica De Largy Healy and Eric Wittersheim

Translator. Dominic Horsfall

\section{Q OpenEdition}

\section{Journals}

Electronic version

URL: https://journals.openedition.org/jso/11127

DOI: $10.4000 /$ jso. 11127

ISSN: $1760-7256$

Publisher

Société des océanistes

\section{Printed version}

Date of publication: 15 July 2019

Number of pages: $5-22$

ISBN: 978-2-85430-137-3

ISSN: 0300-953x

\section{Electronic reference}

Jessica De Largy Healy and Eric Wittersheim, "Introduction. The Pacific on Screens: From Representation to Reappropriation", Journal de la Société des Océanistes [Online], 148 | 2019, Online since 15 July 2020, connection on 21 September 2021. URL: http://journals.openedition.org/jso/ 11127 ; DOl: https://doi.org/10.4000/jso.11127

This text was automatically generated on 21 September 2021.

\section{c) (†) $\odot$}

Journal de la société des océanistes est mis à disposition selon les termes de la Licence Creative Commons Attribution - Pas d'Utilisation Commerciale - Pas de Modification 4.0 International. 


\section{Introduction. The Pacific on Screens: From Representation to Reappropriation}

Introduction. Le Pacifique au cinéma : représentations et réappropriations

Jessica De Largy Healy and Eric Wittersheim

Translation : Dominic Horsfall

\section{AUTHOR'S NOTE}

Translated from French by Dominic Horsfall with funding from the Laboratoire

d'ethnologie et de sociologie comparative (LESC, UPN-CNRS).

1 The Pacific region occupies a unique place in the history of world cinema, covering a wide range of genres, including Hollywood blockbusters, ethnographic documentaries, and contemporary local productions. Despite this, studies on the subject are rare, especially in French-language research. Yet, from the perforated reels of the first cameras to modern-day digital equipment, the Pacific on film raises a number of questions, be it as a vehicle for colonial propaganda, font of exoticism, scientific record, war archive, work of art, or political expression. Our work - political anthropology and documentary filmmaking in Vanuatu (Wittersheim, 2003, 2009; Wittersheim \& Kielar, 2011); and research into restitution and Indigenous media in Australia (De Largy Healy, $2013,2016,2017$ ) - has led us to consider the question of representation, as well as the processes of reappropriation that characterise these audiovisual forms. Processes that relate both to the images produced of the Pacific's Indigenous inhabitants and the tools that make it possible to produce and distribute them. Drawing primarily on our fieldwork in Melanesia and Australia respectively, our converging areas of research have resulted in this joint examination of the role played by moving pictures in the Pacific region. ${ }^{1}$ 


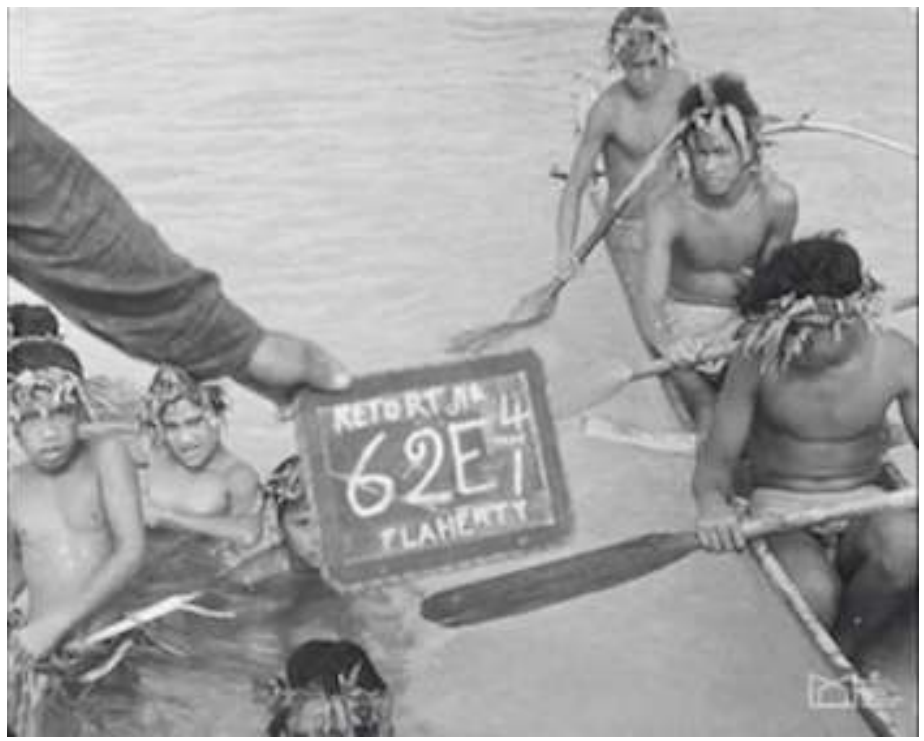

The Making of F.W. Murnau's Tabu. The Outtakes Edition, Take N62E Retort (https://tabu.deutschekinemathek.de). Courtesy of Deutsche Kinemathek

This issue of the Journal de la Société des Océanistes brings together a new collection of articles on the subject of film in the South Pacific. By comparing the visions of authors and filmmakers from the region with case studies - of films, directors, filming practices, and modes of viewership - this volume aims to provide a transversal, multidisciplinary perspective to capture the uniqueness and diversity of the audiovisual material available. Beyond the content of the works themselves, and the debates and questions of power that they raise, this compilation will tackle the cinematographic experience as a whole, from the creative process to film economics, channels of distribution, and reception by the populations concerned.

Pacific cinema remains an emerging field of study, in contrast to Africa, India, and Asia, which have long been subjects of academic focus, and numerous works of reference. ${ }^{2}$ Despite a series of important articles published in the 1990s (Mawyer, 1998; Mellon, 1994; Nelson, 1992; Dening, 1996; Jolly, 1997) and an issue of the Journal of Pacific History ("Film and History in the Pacific", 2010) coordinated by Jane Landman and Chris Ballard, ten years later, there is still little discernible structure to the field of research on the region's cinema. The latter publication emerged from a workshop held at Australian National University in Canberra in 2007, which brought together for the first time historians, anthropologists, and filmmakers to examine the role of cinema in the Pacific's colonial and postcolonial history. Following Australian historian Greg Dening (1996), who previously highlighted Hollywood's role in creating one of the seminal myths of the region's modern history - the mutiny on the Bounty - the introduction reflected on cinema's role as "a particularly powerful medium for communicating the past" (Landman \& Ballard, 2010: 2), especially for historians. Building on the idea that film as essentially a work of construction pieced together through writing and editing, the authors of this issue explored in a heuristic manner the nature itself of cinematic historiography and its sources (ibid.: 5). In this vein, Angels of War (1981), produced by some of the region's most prominent historians (Andrew Pike, Gavan Daws, Hank 
Nelson), shows the crucial role played by the local populations of Papua New Guinea during World War II, alongside both the Allies (USA, Britain, Australia) and the Japanese.

However, in light of the contrasting effects and reactions elicited by its multiple forms (MacDougall, 1998), Pacific cinema cannot be defined only in terms of the knowledge if brings of the region's inhabitants. As such, this volume does not focus specifically on cinema as an object of historical knowledge - an area that has already been well explored (De Baeque \& Delage, 1998; Ferro, 1988; Rousso, 1991) - nor on its anthropological character. Instead, it examines the medium's ability to highlight power relations, conflicts, and creative initiatives. At the heart of issues of sovereignty, films related to the peoples of Oceania - about them, with them, or by them - are frequently a source of controversy, both in the Pacific region and in the West. ${ }^{3}$ In terms of the films and themes covered here, we look beyond any official filmography of works that might be considered (artistically) "good" or (scientifically/politically) "correct" to all types of films, commercial or otherwise; indeed, any that give us cause to think, in the words of historian Gérard Noiriel (2003): sometimes for, sometimes against.

Despite the significant changes affecting the way in which moving pictures are produced and shared today, with the spread of high-speed Internet and social media, the importance and symbolic value of audiovisual works often derives more from their supposed intellectual and moral worth than from their actual popular appeal. From one form of cinema that has long represented Pacific peoples as objects of curiosity and another, more recently, that has seen them move behind the camera to become auteurs themselves, ${ }^{4}$ the lines between genres are becoming increasingly blurred. We have therefore tried to extend the scope of our study to include all types of audiovisual forms, from the very first fiction films to independent documentaries, from the work of researchers and Indigenous filmmakers to recent Hollywood blockbusters like Disney's Moana (2016).

An analysis of the conditions under which films are produced remains an essential question, revealing different forms of craft and inventive collaborations; or, conversely, a complete lack of local participation. Yet the question of how films are distributed, received, and appropriated by different audiences has, on the other hand, become an indication of the various social, political, and economic issues that the status of these images raises. The documentary value of films as a source of knowledge of the past is now recognised as much by historians as by the descendants of those being filmed, who have increasing access to these images of their ancestors, whether fictional or stemming from a more scientific approach, closer to "reality". In this way, First Contact, by Bob Connolly and Robin Anderson, has become emblematic of the encounter between past Pacific Islanders and their present-day descendants, intercutting reaction shots of Papua New Guineans viewing archival footage of their ancestors (see Ballard, 2010; Connolly \& Anderson, 1987; Connolly \& Morel, 1992; and Maden, this volume).

7 The restitution of old footage to various Indigenous communities and new collaborations between the descendants of those filmed, researchers, curators, and artists are becoming increasingly common across the Pacific region. The scenographic device of interplaying archival footage and viewer reactions ${ }^{5}$ reflects the many ways in which it is now possible for these images to be reclaimed. Screenings of old ethnographic films in Trobriand villages elicited spontaneous narration as a form of reappropriation: the viewing was characterised by direct engagement with the images, 
thus afforded fresh relevance as historical records (Connelly, 2016). Such case studies allow us to revisit notions of reality, and of Indigenous agency, while the changing status of these images over time leads us to take a diachronic approach, reviewing these audiovisual archives "against the grain"; that is, from a different perspective than that intended by those who produced them (Stoler, 2009).

Рното 2. - Poster for Lewis Milestone's Mutiny on the Bounty (1962), starring Marlon Brando

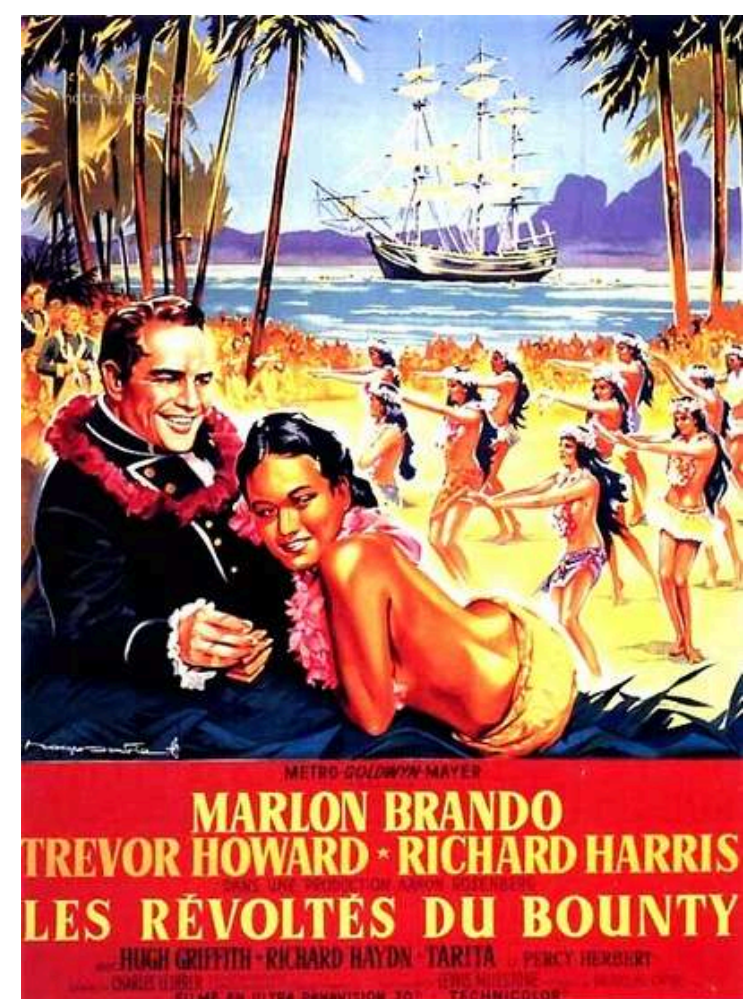

By challenging the codes and criteria that define the status and authorship of works of cinema and Western art in general, by providing their version of the performances and active participation of their ancestors in productions that had until now been considered exclusively exogenous, the reinterpretations of contemporary Oceanians give us cause to reflect: theirs is a more nuanced reading of the nature of the relationship between Europeans and the Indigenous people that they were filming. They also show that, despite the imbalance in social, political and symbolic power relations, there was room for negotiation, whereby locals could offer their expertise, or, conversely, control how much of their culture they would or would not show. The initiative and compromise demonstrated by these strategies of reappropriation also challenge established cinematic paradigms based on broadly Western-centric assumptions of representation.

\section{The Pacific: a Hollywood icon}

Recently, several mainstream movies, such as Disney's Moana, have rekindled an interest in the Pacific that has existed since the first filmmakers. Indeed, there exists a long tradition of Hollywood productions on the subject (Reyes, 1995), from Tabu (Flaherty \& Murnau, 1931) to Elvis Presley's Hawai'ian romances (such as Blue Hawai'i, 
1961, see Lipset, this volume), and the many incarnations of Mutiny on the Bounty that have starred some of the biggest names of the big screen (Errol Flynn, Clark Gable, Marlon Brando, Mel Gibson, etc.). Tahiti and Hawai'i have long been the landmark locations of a filmography based predominantly around exoticism (Louvat, 2017).

Since the invention of the "Kinetograph" by Thomas Edison in 1891, followed by the Lumière brothers' cinematograph in 1895 , which made the projection of filmed images possible, the Pacific has proved a choice location in cinema. Anthropologists, explorers, and filmmakers all rushed to film these South Pacific populations, with whom "first contact" had only been made a century earlier, and even more recently for some. ${ }^{6}$ These expeditions, using some of the very first cameras, capable of recording a few dozen seconds at a time, represented the continuation of an already long-established trend. Throughout the $18^{\text {th }}$ and $19^{\text {th }}$ centuries, the Pacific islands were a source of some fascination in the West, expressed in the form of countless graphic and literary representations. Deconstructed today by Pacific artists such as Lisa Reihana (in her multimedia project In Pursuit of Venus [Infected], 2015-17) or Shigeyuki Kihara (in the Kihara: Living Photographs series, 2008), travel journals, novels, and illustrations of every kind came together to form an edifying vision of the Pacific peoples, highlighting their uniqueness and the strangeness of their customs (Lindstrom, 2016). Discourses and representations relating to the Pacific were for a long time marked by an ambivalent and fantasized perception of cannibals and wahine (Boulay, 2000). To the numerous accounts of anonymous or unknown authors (travellers, merchants, soldiers, missionaries, etc.) were added those of famous writers and artists who joined the Western voyages of discovery to these islands during the era of colonial expansion (Gandin, 1998). From Diderot and Gauguin to Defoe, Loti, London, Melville, and Stevenson, this litany of sometimes peaceful, sometimes troubling images is pervaded by an exoticism akin to "orientalism", the mechanisms of which Edward Said (1980) explored in his seminal work on postcolonial theory.

Рното 3. - Photogram of 100 Tikis. An appropriation video (1996), by Dan Taulapapa McMullin

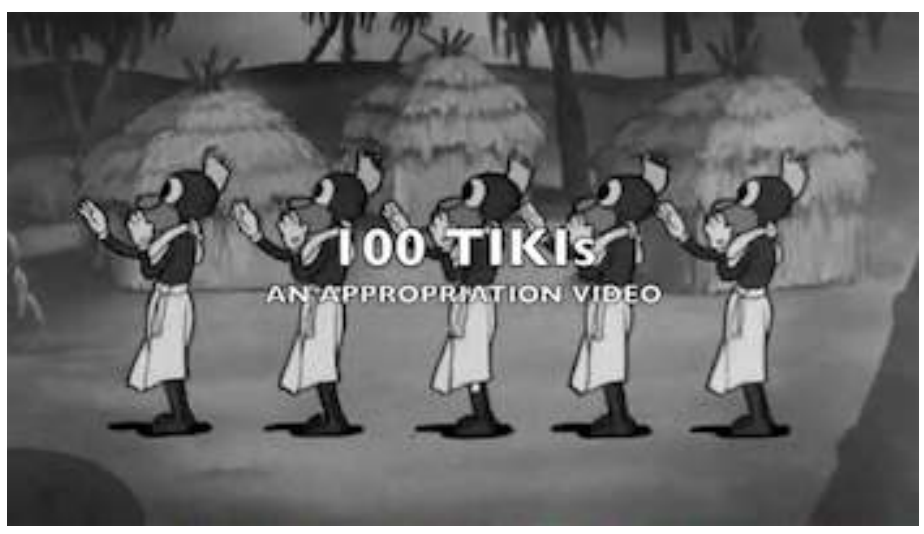

(C D. Taulapapa McMullin)

11100 Tikis. An appropriation video, a film by Samoan artist and poet Dan Taulapapa McMullin, is a remarkable illustration of the proliferation of images that arise from combining the terms "film" and "Pacific". A rapid, patchwork montage of short clips, 100 Tikis merrily draws on everything that the West was able to produce in terms of visual references for the Oceanian world, from Hollywood clichés to tiki pop culture (Kirsten, 2014), and the most farfetched representations of desert islands lost in the 
Pacific and their inhabitants. 100 Tikis comprises extracts from movies, adverts, cartoons, and even self-help videos, all copied from the Internet and reused without permission, as the artist openly and defiantly admitted during a screening of the film at the Rochefort Pacifique Festival in 2018 (http://www.rochefortpacifique.org/festival/ festival-2018/). The stream of stereotypical content is intercut, however, with amateur footage filmed in Hawai'i and New Zealand during protests for Indigenous rights. Playing on different modes of appropriation and reappropriation of images, as well as his professed double identity (Samoan and queer), the artist demonstrates the shifting relationship between filmmaker, subject, and audience. Every individual behind the camera becomes, sometimes unwittingly, a representative of his or her world: Western and global; Indigenous and Oceanian. Or even both, as is the case here. Conceived as an "artistic intervention", this film oddity reflects the political issues surrounding the question of artistic ownership and its reappropriation, as well as Indigenous practices of representation in the Pacific.

As well as contributing to the development of a "mental map" of the Pacific peoples and their supposed specificities (both cultural and physical), a number of motion pictures set in the region represented landmark moments in the history of cinema. Charles Tait's The Story of the Kelly Gang (1906), about the notorious Australian outlaw, is considered by some to be the world's first fiction film. In 1911, Alfred Rolfe's Moora Neya, or the Message of the Spear was the first feature to cast Aboriginal Australians. This coincided with the appearance on film of other colonised Indigenous peoples that we are much more used to seeing depicted on the big screen. Indeed, that same year, Native Americans appeared for the first time in American cinemas (Fred J. Balshofer's An Indian Love Story), marking the beginning of a prolific filmography that would perpetuate a caricatural and negative portrayal of these groups. Gradually, this depiction would develop into a more reflexive form of cinema, distancing itself from the stalwarts of American history incarnated by pioneers and frontiersmen, as evidenced from the evolution of John Ford's (1895-1973) career, from Stagecoach (1939) to the more humanist Cheyenne Autumn (1964) (Balvay \& Cabos, 2015). Stereotypes surrounding Native Americans are humorously deconstructed in Canadian documentary Real Injuns (2009), produced by Neil Diamond, a Cree, with Catherine Bainbridge and Jeremiah Hayes, in which we learn, for example, that the actors playing the roles of Indians were often played by Italian or Jewish Americans, and that the Native American actors would make jokes onscreen in their own language without the directors' knowledge.

13 From the beginning of the $20^{\text {th }}$ century, the South Pacific represented an exotic alternative to the Western genre. Already weary of landscapes of the American West, and in search of new sets and subjects for his films, Gaston Méliès, brother of the famous Georges, who directed A Trip to the Moon in 1902, set off on a round-the-world voyage from 1912 to 1913 with a twenty-strong film crew (Malthête, 1990). Of the sixty or so films produced during this expedition, sadly only a few clips remain today. Stopping off in Tahiti, New Zealand, and Australia, most of these films take the form of idealised documentaries in the style of A Tale of Old Tahiti (1912), which depicted the illfated romance between a European man and a Tahitian woman. While the stars of Gaston Méliès' films are predominantly European, they also feature many Polynesian extras, making them valuable historical sources today, with the first recorded images of Papeete, or such luminaries as the last Queen of Tahiti, Marau Taaroa. ${ }^{7}$ 


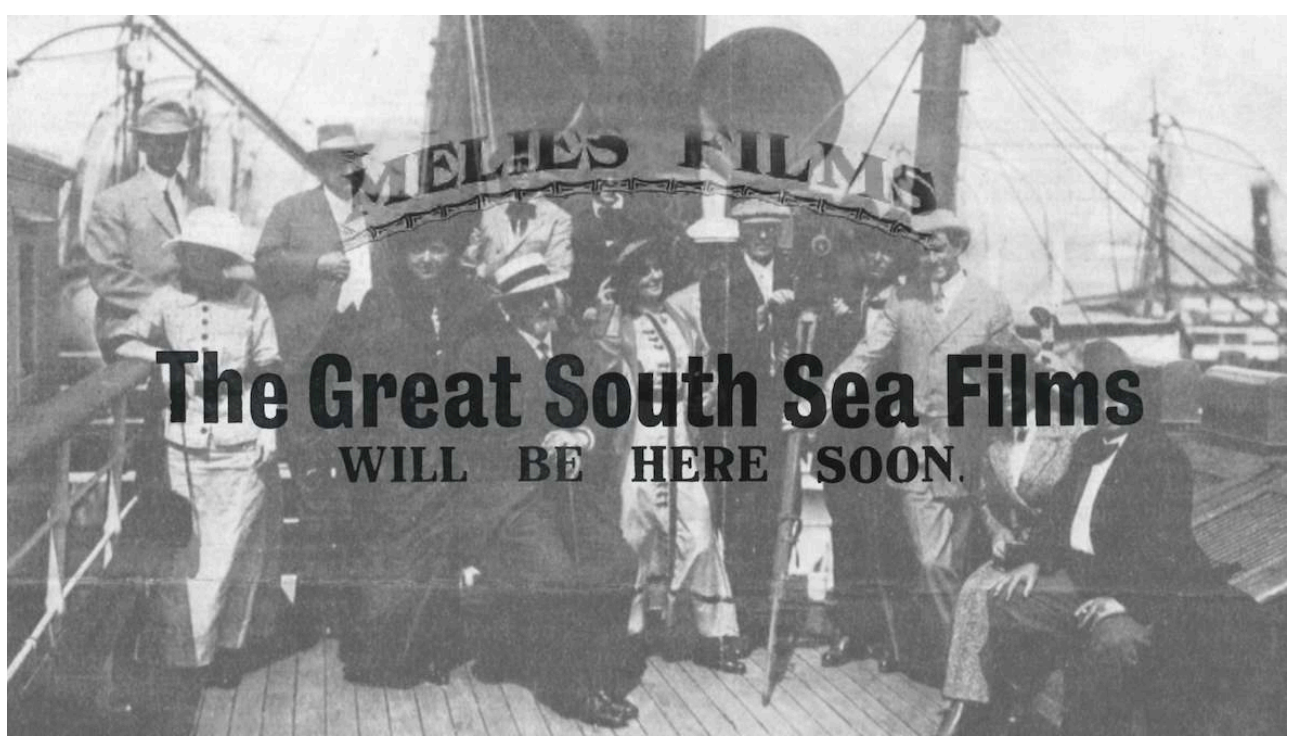

(๔ Nocturnes Productions, reproduced with kind permission of R. Millet)

American filmmaker Robert Flaherty's Moana. The Love Life of a South Sea Siren (1926) is a perfect example of the blend of genres that characterised the first Hollywood pictures. Its production is emblematic of the black-and-white oppositions between authenticity and documentary realism on the one hand, and the inclination toward fiction on the other. A few years after the huge commercial success of Nanook of the North. A Story of Life and Love in the Actual Arctic (1922), Flaherty was sent to Samoa by Paramount Studios to make a similar film in the Pacific islands. The result, Moana, took the form of what today might be called a docudrama or scripted documentary. Flaherty relocated his family with him for the duration of the filming. The director developed his reels as he went along, making copies, and screening an initial cut for the film's participants. $\mathrm{He}$ felt that it was essential to let the Indigenous actors play their own parts and act as they would in everyday life, so as to preserve through his film a culture that seemed to him under threat. As a witness to this rescue mission, his wife Frances later described her memory of leaving Samoa:

"I can still see myself sitting on the deck of the ship taking us home, watching the island fading onto the horizon, thinking about the crates of film piled up in the hold. We were abandoning this ancient Polynesian culture to its death, but, in those crates, we were also bringing it back with us, still alive." (Flaherty, 1970: 11)

As an example of the dual entertainment/scientific quality of Flaherty's films, his widow's autobiographic text, entitled Naissance du film de fiction en Océanie ("The birth of fiction film in Oceania"), was paradoxically selected by Jean Rouch as the introduction to UNESCO's landmark 1970 Catalogue sélectif international de films ethnographiques sur la région du Pacifique. It was also about this film that the term "documentary" is said to have first been used by British filmmaker and film theorist John Grierson (Zéau, 2008). In a twist of fate demonstrating Hollywood's remarkable continuity in its romanticised representation of the Pacific and its inhabitants, Disney's animated feature Moana (2016) was so called as an homage to Flaherty's eponymous film. However, the commercial failure of the original forced its director to work on more mainstream films such as Tabu (1931), "a Story of the South Seas by F.W. Murnau and R.F. Flaherty". This 
film, critically acclaimed for the beauty of its cinematography, is a romantic tragedy about the forbidden love between a young Polynesian couple who have broken the law. Filmed entirely on location in a timeless Bora Bora, with Polynesian actors in the main roles, the script and direction reflect some of the themes held particularly dear to Friedrich Wilhelm Murnau, including innocence and the myth of paradise lost. ${ }^{8}$ This idealised vision of Polynesian women has been the subject of recent critical reinterpretations (see, for example, Jolly, 1997).

Criticism of Euro-centric representations of the Pacific - whether scientific or commercial - has already led to numerous and important works of social science (Smith, 1985; Jolly, 2007; Thomas, 1997, 2010), to which Pacific intellectuals have greatly contributed (Hau'Ofa, 1994; Langton, 1993; Smith, 1999; Taouma, 2004; Teaiwa, 1994; Tengan, 2008). These debates have at times pitted Western researchers against their Pacific counterparts (Wittersheim, 1999). Here, however, following the collective work Après l'Orientalisme : l'Orient crée par l'Orient (Pouillon \& Vatin, 2011), which gives a more nuanced view of symbolic power relations between colonisers and colonised, we prefer to focus on ways in which the Pacific has also shaped itself through the medium of film.

Рното 5. - Poster for Martin Johnson's The Cannibal Isles of the South Pacific (1918)

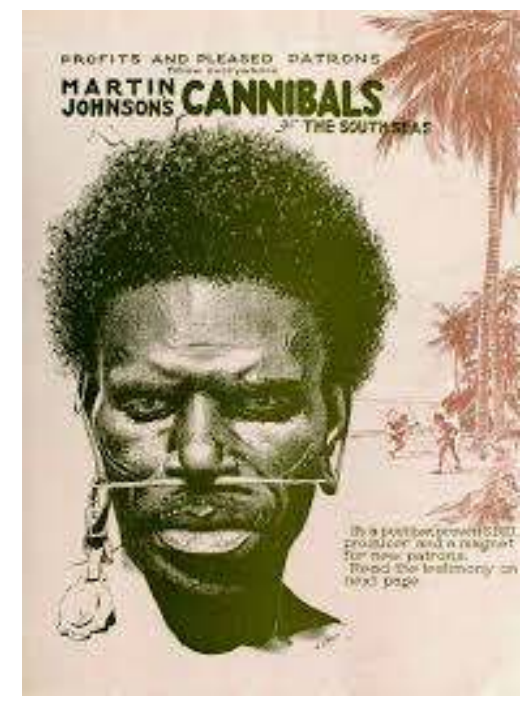

\section{Blurred lines: from documentary to fiction}

The Pacific was the setting for the first use of a camera as part of an anthropological expedition, in 1898, just a few years after the invention of the Kinetograph. Taken in the Torres Strait, north-eastern Australia, these images have remained famous in the history of ethnographic film and documentary cinema. Captured by Alfred Haddon, founder of the Cambridge School of Anthropology, the rare clips that survive today are considered a national treasure in Australia. ${ }^{9}$

The members of the Cambridge anthropological expedition to the Torres Strait stayed on Murray Island (also known as "Mer") for seven months, where they produced a seven-volume written report, one hundred or so recordings made on phonographic wax cylinders, and a few minutes of footage on $35 \mathrm{~mm}$ film captured with a Newman \& 
Guardia camera (Edwards, 1998: 107-108; Griffiths, 2002: 128). Lasting 4 minutes 30 seconds, Torres Strait Islanders (1898) is made up of five sequence shots capturing various practices and ceremonial dances (Griffiths, 1997: 24). Forbidden by missionaries twenty years earlier, we now know that the Malu Bomai ceremony was arranged for the film at Haddon's own request, with paper masks specially crafted for the carefully staged scenes (Griffiths, 1997: 26-29; 2002: 138). The director noted himself how the dancers' performances elicited strong emotions from the community (Haddon, 1901: 47).

most a century later, the same scenes were put forward as "evidence" by the inhabitants of Mer in their land rights dispute with the State of Queensland. ${ }^{10}$ Haddon's film was proof of the continuity of practices, a key aspect of the mechanism allowing Indigenous land claims to be recognised in Australia (Ginsburg, 2002: 51-52; Patrick, 2018).

Impressed by the scientific potential of this new recording technology, Haddon wrote to Australian anthropologist Baldwin Spencer, professor at the University of Melbourne and author of a well-known monograph on Aboriginal totemism (Native Tribes of Central Australia, 1899), encouraging him to bring a camera on his next expedition (Dunlop, 1979). Filmmaker Jean Rouch (1970: 3) paid tribute to Spencer's pioneering works, among them Rain Ceremony, filmed among the Arrernte of the Central Australian desert, which in his view contributed to the "invention of ethnographic film".

The first documentaries filmed in the Pacific occurred as part of colonial enterprises intended to study, record, and bring the traditions of so-called distant peoples to the attention of a predominantly outside audience. The new recording equipment available was quickly put to use in collecting scientific data and material culture for museums. As this "salvage" ethnography developed over the next few decades, in France (Chiva, 1985; Delpuech, Laurière \& Peltier-Caroff, 2018; Laferté, 2017) and elsewhere (Jordan, 1992; MacDougall, 1998), the documentary capacities of cameras were employed in the preservation by new means of cultural practices deemed under threat. To this end, starting in the 1940s, partnerships were established in Australia between universities, museums, government bodies, and independent filmmakers. Through the creation of the Commonwealth Film Unit, and later the Australian Institute of Aboriginal Studies, the Australian government pursued a significant audiovisual policy aimed at preserving Aboriginal traditions (Bryson, 2002).

Beyond anthropological interest in film technology, capable of producing "objective" records of culture in the name of science, the same films could also be marketed in order to finance the expeditions. Film theorist Alison Griffiths even suggests that the first "ethnographic films", from the late $19^{\text {th }}$ century to the 1920 s, be defined as "actuality films featuring native peoples that were produced by anthropologists, commercial, and amateur filmmakers alike" (Griffiths, 2002: xxIx). The British promotional tour for Australian filmmaker Frank Hurley's Pearls and Savages (1921), filmed in the Torres Strait Islands and Papua, demonstrates the commercial as well as scientific ambitions of these first productions. With screenings held at large public events across the country, the film clearly represented a "new type of trophy" brought back from distant lands (Landman \& Ballard, 2010: 8).

In France, Marist Father Patrick O'Reilly (1900-1988), who took part in several ethnographic missions to the Pacific between 1930 and 1950, is today considered a pioneer in the use of film for anthropological purposes. ${ }^{11}$ Commissioned by the 
Ethnographic Museum of the Trocadéro, ${ }^{12}$ he filmed in the Solomon Islands between 1934 and 1935; his film Bougainville (1935) is sometimes listed as the first French ethnographic film and "one of the treasures of the Oceanian cinematographic archives" (UNESCO, 1970: 265). Bougainville shows the Solomon Islanders ${ }^{13}$ engaging in everyday activities, alongside certain key events in their life cycle.

Рното 6. - Still taken from P. O'Reilly's Bougainville (1935), one of the "first French ethnographic films": pot-making ${ }^{14}$

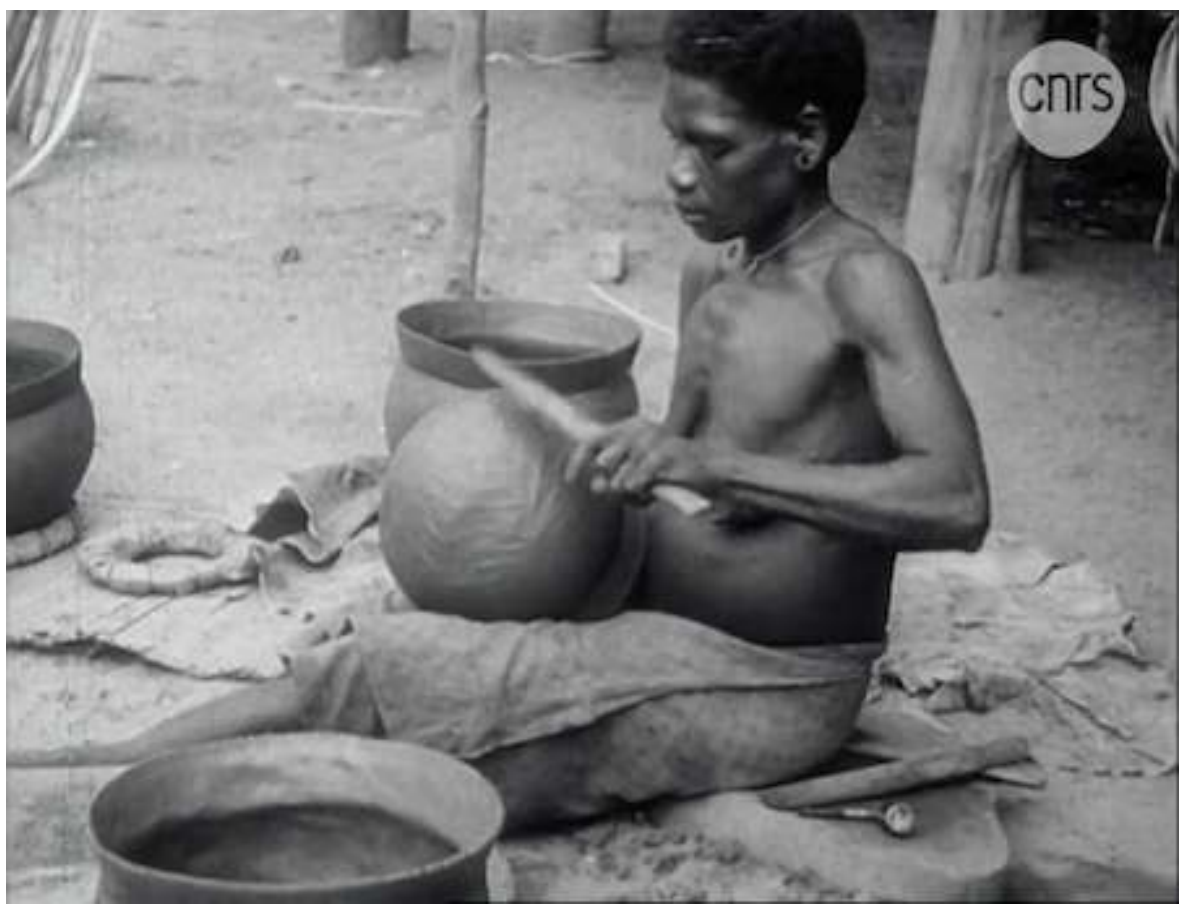

(C) P. O’Reilly)

Simultaneously foreshadowing and embodying the documentary ambitions of the era, O'Reilly explained his approach and the attraction that the camera held for ethnographers by virtue of the scientific objectivity of the facts recorded:

"It would be the dream of any ethnographer to compile on each of the populations that he studies a sort of corpus of moving images, and so record, and revive at will, their various techniques, rituals and ceremonies. One would be as interested by habitual acts - the humble cycle of daily activities, seasonal rites, or annual festivals - as by unique ceremonies, or their reactions to unforeseen events: disease, tsunamis, storms, eruptions, war. Ideally, one would seek to create a traditional archive for a given population, through the meticulous and careful documentation of their various activities; to compose a pure record, one that is as objective and precise as possible." (O'Reilly, 1949: 119)

In 1949, O'Reilly published the first inventory of “ethnographic documentary in Oceania" in the Journal de la Société des Océanistes. In this seminal article, a clarion call to all scientists to pick up a camera, he highlighted the variety of documentary images that could be grouped under the "ethnographic" label. His critical repertoire of twentyfive titles places anthropological films alongside expeditionary films, newsreel, adventure films, and Hollywood romances, each genre having, in his view, its own “ethnographic value” (O’Reilly, 1949: 118). The same variety of resources and blurring of genre lines can also be seen in the Rapport sur les films réalisés par des cinéastes français 
dans la région du Pacifique sud (1966) compiled by Marie-Charlotte Laroche for the Société des Océanistes. Using O'Reilly's repertoire as a basis, this report, prepared for UNESCO's roundtable discussion on ethnographic film in the Pacific, included a panoply of works labelled "quasi-historical" on Oceanian societies that at the time were undergoing great upheavals.

The 1966 UNESCO conference in Sydney brought together one hundred filmmakers and anthropologists from the United States, Australia, New Zealand, and France, and was a landmark moment in the recognition of Pacific film. It was the first acknowledgement of the fact, as Jean Rouch wrote, "that contemporary social anthropology was born on this continent, as well as the first attempts to capture on film ways of being, of doing, and of thinking" (Rouch, 1970: 13). Following the roundtable, a Catalogue sélectif international de films ethnographiques sur la région du Pacifique (1970) was published, as had previously been done for African cinema (UNESCO, 1967). Enshrining the logic of genre-mixing, the report listed - already at this date - 341 films, including the famous Hollywood fiction features. ${ }^{15}$

The post-war appearance of smaller, more mobile cameras, followed by the development of synchronous sound recording and subtitling in the late 1960s, constituted two more important milestones that proved revolutionary for many directors in their approach to producing ethnographic films in the Pacific region. Filmmaker and film theorist David MacDougall offers a neat overview of the paradigm shift caused by the spread of these techniques. Now, audiences were no longer just receiving verbal information about the peoples of the Pacific, but were in fact beginning to see and hear them directly (MacDougall, 1995). By giving a voice for the first time to those being filmed, these films could now echo political messages and be used locally as a means for the transmission of culture (see Maden, this volume). This new possibility to reproduce the voices of the filmed subjects and so document their subjectivity through moving pictures was part of a wider movement that began in anthropology and ended in the reflexive shift of the 1980s (Clifford \& Marcus eds, 1986). For anthropologist Howard Morphy, the visible changes in ethnographic films that began in the 1960s foreshadowed the transformations to come in the discipline: staging the dialogical nature of anthropological research (the director's appearance onscreen in Ian Dunlop's films on the work of Maurice Godelier among the Baruya of Papua New Guinea); acknowledging the participants' agency (who could address the camera, or even direct it themselves); researching new ways to communicate certain concepts through visual media (Morphy, 2012: 10). Today, filming conditions have to be negotiated in advance with the Indigenous participants, opening up a new reflexive horizon for ethnologists to contemplate their own practices of representation and the sometimes unexpected effects that their cameras can have on the place in question; as in Stéphane Breton's Eux et moi (2001) or André Iteanu and Eytan Kapon's Reviens Demain (2009) (see also: Henry \& Vavrova, 2016 and Malogne-Fer, this volume).

Although the myth of objectivity in ethnographic films has been questioned within the discipline since the early 1970 s, this same quality of objectivity is being emphasised today by the descendants of those who were filmed. Historically, the Yolngu of Yirrkala were pioneers in the use of audiovisual documentary techniques (De Largy Healy, 2013; Deger, 2016). In this Aboriginal community, old ethnographic films are actively sought out and watched as records of memory, as well as tangible, vivid traces of their ancestors. The films of Australian director Ian Dunlop's Yirrkala Film Project (2017) are 
even considered genuine Yolngu artefacts. ${ }^{16}$ For them, there is no doubt that these are their films, similar in this sense to other forms of representation that they produce (De Largy Healy, 2017). The popular use of cameras to record certain aspects of culture and create audiovisual resources for future generations is thus becoming increasingly common across different territories (see Van der Ryn, this volume). Collaborations between anthropologists, Indigenous peoples, and filmmakers - like the Karrabing Film Collective, a joint project by thirty-odd Aboriginal Australians of the Belyuen community in the Northern Territory and American anthropologist Elizabeth Povinelli; or Miyarrka Media, in Arnhem Land, by anthropologist Jennifer Deger, ritual expert Paul Gurrumurruwuy, and other members of his family - constitute a new creative response to this ethically and politically charged question, challenging old classifications between cinematographic genres.

\section{Toward an Oceanian cinema}

These processes of reappropriating images and the tools of audiovisual media ultimately raise the question of whom these films really belong to. Clifford's now classic remarks (1988) on the contesting of "narrative authority" by local populations are particularly relevant in the context of representation in film. In their book on In the Land of the Head Hunters, shot by the great American photographer Edward S. Curtis in British Columbia, Evans and Glass (2014: 13) argue that this 1914 classic - the first feature-length film about native North Americans in British Columbia - should be viewed as an intercultural production. Considered a "sign of emerging indigenous modernity", the filming already involved, according to Evans and Glass, a "conscious performance of their past" on behalf of the actors. Similarly, the films of the Yirrkala Film Project can be viewed as the product of encounters between the different protagonists of the various shoots (Deveson, 2011). These particular cases lead us to reconsider the question of authorship ${ }^{17}$ between individuals representing, sometimes unwillingly, two seemingly opposite worlds. Whether expressly designed as a collaborative project or critically reinterpreted from an Indigenous perspective to bring out the agency of the filmed subjects, these ethnographic films also show how certain groups, like Aboriginal Australians, employ modern strategies of selfaffirmation that use public performance and self-representation on film as their media of choice. The fact that, today, the descendants of those seen in historical films are now producing their own works in response - such as the three films of the Yirrkala djungguwan ceremony, each made at the community's request more than forty years apart - is particularly useful in charting the evolution of these filming practices and political and memorial issues that they raise (De Largy Healy, 2017). 
Рното 7. - Aaron Pedersen and David Gulpilil in Goldstone (2016), an award-winning thriller by Australian Indigenous director Ivan Sen

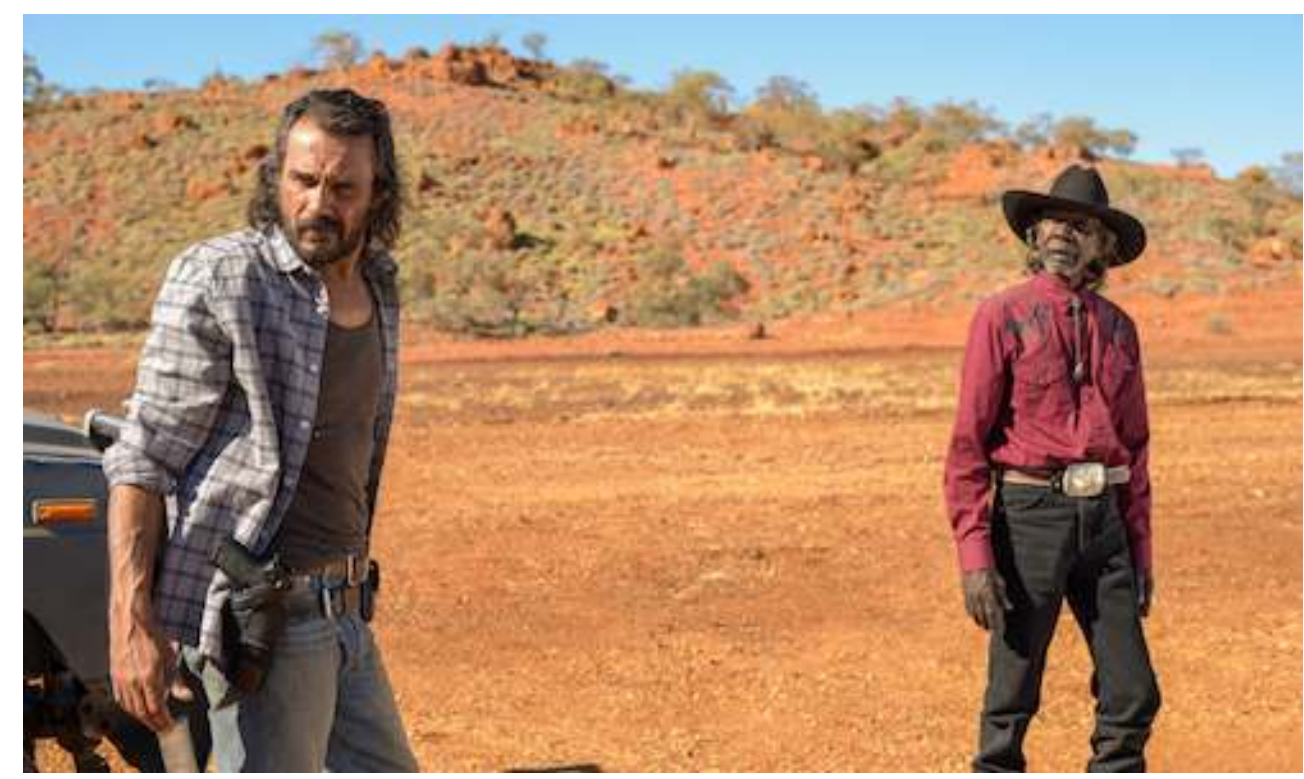

(C) Goldstone)

Reinterpretations of this kind, that deviate from the original intentions of the filmmakers, can also be applied to reality TV shows, such as Meet the Natives (2007), a documentary series broadcast on Channel 4 in the UK. A great success at home (and later adapted for American television), the original series featured five men from Tanna Island in Vanuatu come to explore modern Britain and "observe the natives...of this strange and exotic land" (cf. Meet the Natives, 2007 and 2009). ${ }^{18}$ The show was also popular with the island's native inhabitants, who enjoyed following the exploits of their family members onscreen. And yet, as Solomon Islander researcher Tarcisius Kabutaulaka (2015) suggests, in films that place Papuans or other Oceanians front and centre, intending to offer "their" perspective on the West, it is often the (noble) savage that remains the object of curiosity. Indeed, this enticing, though somewhat demagogic notion of a "reverse anthropology", of the type displayed in these shows, could arguably be seen as perpetuating an exoticizing tropism.

31 This question also arises in Australian reality TV show First Contact (2014), which followed a group of white Australians, each with varying degrees of prejudice, and their encounters with various Aboriginal communities. Made by public broadcaster SBS, then by Indigenous production company Blackfella Films in the second season, the series' aim was to challenge one side's prejudices by exposing them to the social and economic reality of the other. Variously described as a modern "black magical mystery tour" or a pretext for yet another Western journey of self-discovery, some episodes were also criticised by the Aboriginal hosts, among them the Yolngu residents of Elcho Island, who lamented the show's unfavourable depiction of their community.

Since the 1980s, the number of Pacific filmmakers emerging on both the national and international scenes has steadily increased, offering new stories and alternative interpretations of different Indigenous situations, both past and present, through audiovisual output that continues to subvert established genres. These works derive from processes that see people reclaiming their own history, exploring mythology, 
colonisation, or contemporary issues while highlighting their own critical perspectives, knowledge, heritage, spirituality, and diverse forms of creativity (De Largy Healy \& Glowczewski, 2014). These creative experiences of self-representation relate to what Amerindian researcher Michelle Raheja calls "visual sovereignty" (2007), a demand shared by many Indigenous groups reflecting a common desire to overturn the shallow and often stereotyped images perpetuated by traditional media. For American anthropologist Faye Ginsburg (2005), pioneer in the study of Indigenous media, this is a form of activism that should be considered both as a mode of cultural creativity and a mode of social action used to highlight cases of injustice or those conflicts often ignored in "mainstream" media, or else shown exclusively from a Western-eye view.

This recent Indigenous production includes cinema and videos, and, increasingly, formats produced for the small screen and online. ${ }^{19}$ In Australia and New Zealand, Indigenous content has largely been driven by dedicated public television channels (National Indigenous TV in 2007, Maori TV in 2004). Since independence, countries like Papua New Guinea or Samoa have aimed, with greater or lesser success, to develop the necessary infrastructure for the creation of local content (see Bonnemère, Larcher, this volume). These productions reflect the different ways in which South Pacific societies choose to represent themselves onscreen, both for themselves and an increasingly global audience. While some remain relatively obscure, others reap prizes at international festivals, such as Vilsoni Hereniko's The Land has Eyes, the first fiction feature length film shot entirely in the Rotuman language, selected for the Sundance Festival and Fiji's official submission for the 2005 Academy Awards. Others find millions of views on YouTube and social media (De Largy Healy, 2013). These productions offer a glimpse, to ever greater numbers, into situations, behaviours, worldviews, and sensitivities that until recently had only been accessible through the mediation of Western anthropologists, journalists, documentary and feature filmmakers.

Conflicting memories over the interpretation and reappropriation of history go hand in hand with the act itself of making these films, underlining the importance of Indigenous voices in the modern world (Bosa \& Wittersheim, 2009). This can be seen from the issues and tensions raised during the making of certain films that depict key episodes from the region's history, such as the War in the Pacific in Terrence Malick's The Thin Red Line (1998), which anthropologist Christine Jourdan worked on; or Matthieu Kassovitz's Rebellion (2011) about the Ouvéa cave hostages affair (see Faurie \& Nayral, 2012; Leblic, 2012). The deep wound left by this dark episode in French history, combined with conflicting interpretations of the "events" that occurred in New Caledonia forced the famous director of La Haine to shoot in French Polynesia instead. The fact that Kassovitz, who opted not to work with any experts on the matter, made his film from a GIGN gendarme's point of view did not provide the ideal conditions for a collaborative project with the inhabitants of Ouvéa Island. This despite his statements in support of Kanak independence fighters, and the ties he built with the Gossanah tribe on Ouvéa over the course of eight years and twenty-five different scripts during preparation for the film. Knowing who is telling the story (Smyth, 1992; MacDougall, 1991) and which story is being told can sometimes seem more important to Oceanians than the form of the narrative itself (e.g. documentary, fiction, reality TV).

рното 8. - Nancy Brunning in Mahana (released internationally as The Patriarchy, 2016), by Lee Tamahori, who also directed Once Were Warriors (2001) 


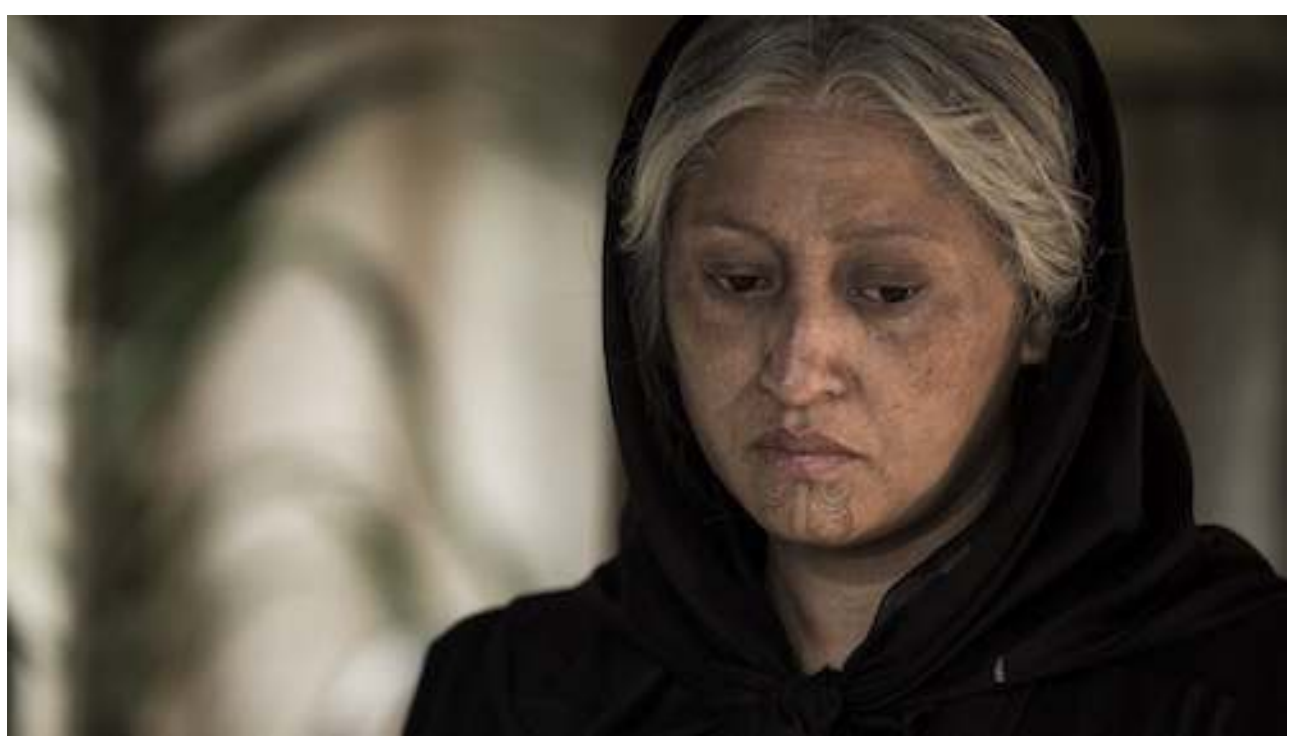

(๔) Mahana)

The processes for the reception and reappropriation of films can vary greatly depending on the location, even stoking tensions within local communities. There is heated debate coming out of Oceania: the considerable success of Lee Tamahori's ${ }^{20}$ Once Were Warriors (1994), which transposes the supposedly warlike character of the ancient Maori to the Auckland suburbs, reinforcing clichés of masculinity and violence, ${ }^{21}$ divided opinion. In a 2009 viral lecture entitled Once were gardeners (https:// www.youtube.com/watch?v=HfAe3Zvgui4), New Zealand lawyer Moana Jackson highlighted the degree to which this caricatural portrayal overshadowed other important aspects of Maori culture, such as the fact that everyone in the old Maori world had a garden. ${ }^{22}$ Nonetheless, these same aggressive depictions, including the famous haka of the All Blacks national rugby team, have proved a key factor in the political recognition of Indigenous groups in New Zealand.

\section{Twelve perspectives on audiovisual practices in Oceania}

The articles in this issue have been grouped into four thematic areas according to the questions posed by their authors. The first set relates to the history of cinema in Papua New Guinea, little-known in France, and in particular to the filmmakers that have chronicled the country's decolonisation since the 1970s. The cinema of this period is marked by the upheavals that came from the lead-up to independence in 1975, including in its aesthetic choices, framing, and editing. Papua New Guinean filmmaker Martin Maden, a disciple of direct cinema, trained in the French documentary school founded by Jean Rouch and Ateliers Varan, offers a unique account of filmmaking practices and cinema in Papua New Guinea since the cinematographic golden age and dynamism of the 1970s. His article refers to the "decolonisation of the camera", linked to the unlikely popularisation of the very French notion of cinéma d'auteur in Papua New Guinea, and the emergence of a new genre of his own making that he describes as "process film". In their respective contributions, Pascale Bonnemère and Jonathan Larcher profile two leading figures of ethnographic documentary: Chris Owen 
(1944-2018) and Dennis O'Rourke (1945-2013). These two figures maintained close relationships with the first independent governments of Papua New Guinea, with their works constituting major references, each in their own way, for understanding the country's decolonisation. The authors also demonstrate how cinema can influence politics, and how politics in turn can influence cinema. Beyond providing historical accounts of this key period in Papua New Guinean cinema, they also show how a cinematographic genre can be shaped by - and sometimes in spite of - the world around it.

Our second set comprises articles on American cinema (particularly Hollywood), which has, as we have seen, produced many films on the Pacific, from the first historical documentaries to the most recent blockbusters. Vilsoni Hereniko, writer of the acclaimed The Land Has Eyes, offers fresh and personal remarks on the question of authenticity in film based on the highly contrasting experiences that forged his perspective: the renowned writer and director from Rotuma, a small Polynesian enclave of the Fiji islands, is a professor at the University of Hawai'i. He explores what makes it possible for cinema to capture (or not) that which is authentically Oceanian; not another carbon copy set piece, as in so many biopics or historical movies; but rather in the more subtle, fluid, and free manner of Pacific intellectuals such as JeanMarie Tjibaou (Tjibaou, 2006; Clifford, 1998) or Epeli Hau'Ofa (1994). These individuals laid the groundwork for a new definition of authenticity based above all on the sincerity of the relationship that Oceanians have with their culture - cosmopolitan yet rooted. ${ }^{23}$ David Lipset aims to trace a genealogy of "Pacific Islander" representations in Hollywood films from the 1950s to the present day. Examining three successful films from different time periods, he shows how the anthropological concept of the "moral person" can be used to grasp the characterisation of Polynesian people in film, one that he shows has remained relatively unchanged over time. Finally, Marie Salaün and Mirose Paia's article discusses the controversy generated by the release of Moana in Tahiti, focusing on the film's reception and reappropriation there, particularly in primary schools, for which Disney financed (and later handed out) a dubbed version in the Tahitian language.

The third set examines how Oceanians have come to represent the epitome of indigenous alterity. The first two articles relate to the inhabitants of Tanna Island in Vanuatu, well known in anthropology, as well as film and television, alternatively for their famous John Frum cargo cult and for their so-called traditional, pagan way of life, distant from the Western world, dictated by principles of kastom (custom). Margaret Jolly reflects on the production conditions behind the multi-award-winning Tanna (2015), by Australian filmmakers Martin Butler and Bentley Dean. Her study of how the film was received locally reveals an ambivalent relationship with exoticism among the population concerned, and with the figure of the noble savage, embodied here by respect for kastom; that is, for custom itself, and social order in general. In his contribution, Marc Tabani examines the history of the different depictions of "man Tanna", sometimes portrayed as acculturated Indigenous people poorly adapted to Western modernity; sometimes as authentic savages from before the Fall, ignorant of Western, biblical original sin. Finally, Polynesian writer Chantal Spitz tackles Hollywood clichés and colonial stereotypes, where racism and sexism vie for position, condemning the film industry's domination by non-Indigenous people, and vibrantly 
calling for "emerging an Indigenous cinema", with particular emphasis on the need for local production and training infrastructure, as well as festivals.

The final set of articles relates to the documentary usages of film, examining the role that images can play in different contexts. Gwendoline Malogne-Fer revisits the production and reception of her film Pain ou coco. Moorea ou les deux traditions (codirected by Yannick Fer, 2010) in French Polynesia. She reflects critically on how the camera has helped uncover ethical and deontological questions that pertain specifically to fieldwork and research. Micah Van der Ryn investigates the practices of a team of American Samoan teachers (himself included) that took part in an audiovisual project in the 1990s to document cultural heritage. With this case study, he defends the idea of a visual anthropology in service of the populations in question. Finally, Eric Soriano traces the development of an amateur practice of cinema through the eyes of gendarme Robert Citron: his home movies, as seen in Gilles Dagneau's dedicated documentary (Le Gendarme Citron, 2008), shed new light on the relationship between Europeans and colonised peoples in New Caledonia during the 1950s and 1960s, when the Kanak were granted citizenship and the right to vote, yet deep colonial divisions still lingered alongside glaring social inequalities.

Рното 9. - Scene from Eric Wittersheim's Grassroots, those who vote (2003), winner of the 2004 FIFO Jury Prize

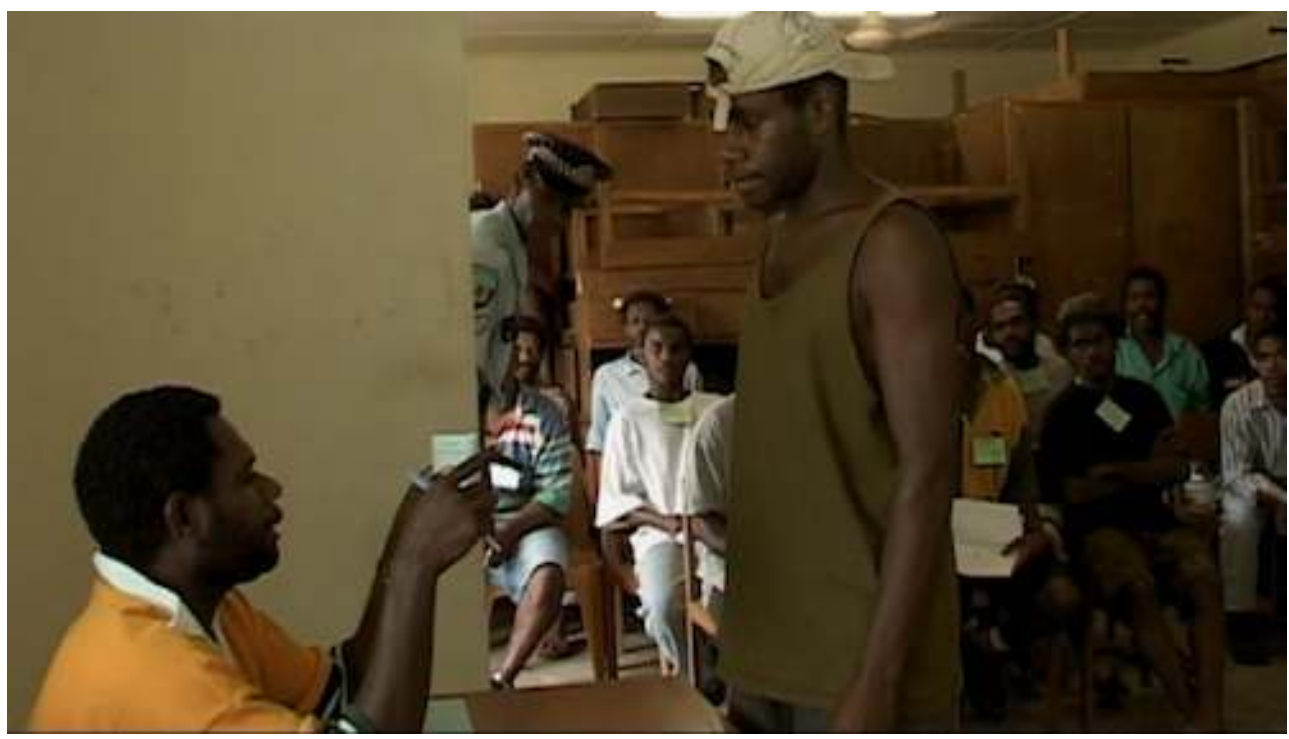

(๔ Eric Wittersheim)

\section{Conclusion}

The filmography of the Pacific does not exist as a separate corpus detached from the rest of cinematic history, and should as such be re-examined as part of a more global context. Filmmaking in this region, as elsewhere, has often blurred the lines between different genres: Hollywood film crews arrived in the region's islands at the start of the last century in the footsteps of the first explorers and pioneering anthropologistfilmmakers. From the 1970s, as various island nations were gaining independence, the Pacific inspired a number of works that have now become classics of direct cinema, among them Dennis O'Rourke's classic Cannibal Tours (1988), and Bob Connolly and 
Robin Anderson's renowned Papuan trilogy, which won the prestigious Cinéma du Réel prize three times, for First Contact (1983), Joe Leahy's Neighbours (1989), and Black Harvest (1992). Following the tradition of Jean Rouch and Richard Leacock in particular, and distancing themselves from anthropological discourse and constraints, these works broke with the naturalism and quest for authenticity that until then had been prominent in classical ethnographic cinema (Rouch, 2009; Colleyn, 2012).

41 Through these works, and those that they were producing in increasing numbers during this period, Oceanians were becoming actors in the true sense, no longer content to simply "illustrate" a culture (J. Bazin, 2002) through rituals re-enacted for the sake of films. Today, these same Indigenous peoples are embracing audiovisual media for political and artistic ends, and for cultural transmission. Oceania's emerging cinema now draws meaning and legitimacy from different sources, leaving behind questions of genre lines and the internal debates on authorship and art associated with Western cinema. The forms and interpretations of these various representations now constitute central issues of power and sovereignty, as most of the studies here demonstrate.

The live streaming of the Christchurch attack (15 March 2019) serves as a painful reminder of the sheer scale on which images can now be shared across social networks such as Facebook (itself highly popular in Pacific nations). As such, we cannot claim to be exhaustive in the subjects and the kinds of films covered in this volume. The rapid proliferation of satellite dishes and digital recording technologies and devices since 2000 has propelled the Pacific region into a new audiovisual era. The global impact that ethnographic films and Hollywood movies once had on Islander societies now appears to have been surpassed by that of moving pictures in a broader sense (amateur footage, music videos, etc.), widely shared via streaming platforms such as YouTube. In Vanuatu, just twenty years ago, Television blong Vanuatu (TBV) would only broadcast a few hours a day, and then almost exclusively to viewers in the capital Port Vila. As the country's government-owned and exclusive channel, TBV's sole competition was from the vHS tapes which circulated from village to village, at least where people had access to a VCR, a television, and a generator. During Eric Wittersheim's first fieldwork in Vanuatu in 1997, he encountered villagers from the south of Malakula still making their way through the numerous games of the previous FIFA World Cup (Brazil 1994) as they waited for the matches to reach them on tape, joking that there was still a little time left before the next competition in France the following year. This also goes to show the legendary robustness of vHS technology, which explains its relative longevity (1980s-2000s). ${ }^{24}$

The number and variety of images sweeping the countries of the Pacific has grown exponentially over the last twenty years. High-speed internet, mobile phones, and satellite TV have revolutionised the way in which images are consumed, providing the people of the region with a huge range of audiovisual content about them. Yet this content is eclipsed by an infinitely greater array of films on entirely different subjects. Journalist Wallès Kotra, a native of the small island of Tiga in Kanaky/New Caledonia, director of Outremer programming for France Télévisions, and founder of FIFo (Festival international du film océanien de Tahiti), summarises this situation with a parable steeped in irony. During public appearances, he often compares the Pacific's cultural submersion beneath a deluge of images from the sky to the rising seas threatening the physical integrity of their island territories (https://blogs.mediapart.fr/fifo-tahiti/ 
blog/220216/les-peuples-du-pacifique-veulent-raconter-leurs-histoires). In her article, Chantal Spitz uses the same disturbing metaphor of a cultural tsunami to underline the crucial role played by FIFO, which was established as:

"a cry of existence and a challenge to the world proclaiming demanding declaiming (clamer réclamer déclamer) the survival of Oceanian cultures and languages, and the subsistence of the peoples and islands of the Pacific overwhelmed by waves of satellite images and submerged beneath uncaring and inexorable rising waters."

FIFO was established in 2004 by Wallès Kotra and Heremoana Maamaatuaiahutapu ${ }^{25}$ in direct response to this situation of structural imbalance:

"How can we make a small, local industry of our own; how can we make our stories more visible on different pipes?" (cf. https://la1ere.francetvinfo.fr/polynesie/ 2012/02/10/videos-le-fifo-bat-son-plein-3456.html)

Audiovisual production in the Pacific has seen an unprecedented boom over the last twenty years, with its own channels, web portals, and forums, supported by a considerable network of festivals, including FIFo (Festival international du film océanien, Tahiti), Ânûûrû âboro (Pondimié, New Caledonia), Rochefort Pacifique, the Rencontres internationales du cinéma des antipodes (Saint Tropez), the Festival du cinéma aborigène australien (Paris), and the Festival du film insulaire (île de Groix), to name just a few, Francophone examples. We are observing an increase in Indigenous film output: documentaries, but also fiction, particularly from Australia and New Zealand, where there is an important professional film market, out of which a considerable industry (film and television) has developed, specifically, though not exclusively, aimed at an Indigenous Pacific audience. For cinema is indeed an industry, as André Malraux recognised early on in his Esquisse d'une psychologie du cinema (1939). The region's two most populous countries have dedicated TV channels (Maori TV in New Zealand, NITV in Australia). Oceanian dramas have found international audiences, like Samson \& Delilah (Warwick Thornton, Australia, 2009, Caméra d'Or at Cannes), or The Whale Rider (Niki Caro, New Zealand, 2002). ${ }^{26}$ But a significant art scene is also emerging (galleries, schools), largely thanks to Indigenous artists (Castro-Koshy \& Le Roux, 2016).

This volume can only reflect a small range of the variety of these experiences. Regrettably, we have been unable to give due attention to the considerable amateur output of recent years, facilitated by the Internet, social media, and the massive proliferation of mobile phones, which today make it possible for a majority of Oceanians to watch, create, and share moving pictures at will. There is no shortage of pornography, violence, B movies, short clips, and amateur tourist videos, as 100 Tikis pointedly shows with humour. But these same platforms have also made it possible, through new forms of reappropriation, for self-produced and self-financed works to find unexpected success, such as Stallone Vaiaoga-Ioasa's Three Wise Cousins (2016), which premiered in New Zealand in a local cinema through the sale of pre-purchased seats online. The launch of the first national communications satellite in the Central Australian desert in the early 1980s had its own unforeseen consequence: "the Aboriginal invention of television" (Michaels, 1986). Taking advantage of the Broadcasting for Remote Aboriginal Communities Scheme, the Warlpiri began hijacking the airwaves to broadcast their own videos, filmed on their own terms according to their own social organisation, then shared among their communities on VHS (Michaels \& Kelly, 1984; Michaels, 1994; Hinkson, 2002). This DIY approach emerged from an established regional tradition of enterprise and sharing alternative ideas and practices, 
which have long served South Pacific societies as a tool of resistance against colonialism.

Issues of "visual sovereignty" should be understood in relation to other sovereignty issues, political or economic. This leads us to think that the question of Pacific cinema should be regarded in terms of its specificity, as well as its more global, universal aspects. The sheer diversity of forms and implementations of moving images cannot be reduced to a few predetermined genres. While cinema certainly helped during the colonial era to establish the opposition between savage and civilised man, the cornerstone of Western domination, it later proved instrumental, through various symbolic acts of reappropriation, in dissolving this barrier between Indigenous peoples and the West, between anthropologist and informant, between filmmaker and filmed.

It is important to consider the film industry as an autonomous market and cultural domain, criss-crossed by the discourses, representations, and perspectives of individual authors. The Pacific is unique, however, insofar as many of its filmmakers are linked, sometimes unwillingly, to groups with powerful claims relating to their Indigenous status, over territorial rights, for example, or more generally over symbols of national identity. From individuals representing only themselves to associations acting on behalf of specific social groups, these Islanders' perspectives on Oceania demonstrate the arguably undefinable nature of the terms "cinema" and "Pacific". We would venture that, with the continuing emergence of noteworthy forms, works, and authors, and innovative new studies into moving pictures today, the Pacific will eventually take its rightful place in a global filmography, alongside Africa, Asian, and beyond.

\section{BIBLIOGRAPHY}

AOKI Diane, 1994. Moving images of the Pacific Islands: a guide to films and videos, Honolulu, Center for Pacific Islands Studies, School of Hawaiian, Asian, and Pacific Studies, University of Hawai'i. BAEQUE (DE) Antoine et Christian DELAGE (éds), 1998. De l'histoire au cinéma, Bruxelles, Éd. Complexe. BALLARD Chris, 2010. Watching First Contact, Journal of Pacific History 45 (1), pp. 21-36 (DOI : 10.1080/00223344.2010.484164).

BALVAY Arnaud et Nicolas CABOS, 2015. John Ford et les Indiens, Paris, Séguier.

BAZIN André, 1976. Qu'est-ce que le cinéma ? Paris, Le Cerf.

BAZIN André, 2002. L'anthropologie en question : altérité ou différence ?, in Y. Michaud (éd.), Université de tous les savoirs. L'Histoire, la sociologie et l'anthropologie, Paris, Odile Jacob, pp. 77-91. BENALI Abdelkader, 1998. Le cinéma colonial au Maghreb : l'imaginaire en trompe-l'œil, Paris, Cerf. BERGER Bernard, 1983-2005. La Brousse en folie, série de bande dessinée, 24 albums, Paris, éd. Télé 7 jours puis Les Nouvelles Hebdo.

BHATTACHARYA Rini, Metha and Rajeshwari V. PANDHARIPANDE (eds), Bollywood and Globalization: Indian popular cinema, nation, and diaspora, London \& New York, Anthem Press, 2010. 
BOSA Bastien et Eric WITTERSHEIM, 2009. L'irruption de la question indigène, in B. Bosa et E. Wittersheim (éds), Luttes autochtones, Trajectoires post-coloniales : Amériques, Pacifique, Paris, Karthala, pp. 9-16.

BOUKARY Sawadogo, 2019. African Film Studies: an introduction, Abingdon, Oxon, New York, NY, Routledge, 2019.

BOULAY Roger, 2000. Kannibals et vahinés : imagerie des mers du Sud, La Tour d'Aigues, éditions de l'Aube.

BRYSON Ian, 2002. Bringing To Light: A History of Ethnographic Filmmaking at the Australian Institute of Aboriginal and Torres Strait Islander Studies, Canberra, Aboriginal Studies Press.

CASTRO-KOSHY Estelle et Géraldine LE ROUX, 2016. Introduction. Creative Collaborations, Dialogues, and Reconfigurations: Rethinking Artistic, Cultural, and Sociopolitical Values and Practices with Indigenous people in Australia, French Polynesia, New Caledonia-Kanaky, and Papua New Guinea, Anthrovision 4.1, 12 p. (http://journals.openedition.org/anthrovision/2191).

CHIVA Isac, 1985. Georges-Henri Rivière, un demi-siècle d'ethnologie de la France, Terrain 5, pp. 76-83.

CLIFFORD James, 1996. Malaise dans la culture. L'ethnographie, la littérature et l'art au XXe siècle, Paris, éditions de l'école nationale supérieure des Beaux-Arts.

CLIFFORD James and George MARCUS (eds), 1986. Writing Culture. The Poetics and Politics of Ethnography, Berkeley, University of California Press.

COLLEYN Jean-Paul, 2012. Champ et hors-champ de l'anthropologie visuelle, L'Homme 203-204, pp. 457-480 (DOI : 10.4000/lhomme.23256).

CONNELLY Andrew, 2016. Pikisi Kwaiyai! (pictures tonight!): The screening and reception of ethnographic film in the Trobiand Islands, Papua New Guinea, The Australian Journal of Anthropology 27 (1), pp. 3-29.

CONNOLly Bob and Robin ANDERSON, 1989. Premier contact. Les Papous découvrent les Blancs, Paris, Gallimard.

CONNOLLY Bob and Alain MOREL, 1992. Rigueur et passion. Entretien avec le cinéaste Bob Connolly, Terrain 19, pp. 159-170.

DEGER Jennifer, 2006. Shimmering Screens. Making Media in an Aboriginal Community. Minneapolis, London, University of Minnesota Press.

DE LARGY HEALY Jessica, 2013. Yolngu Zorba meets Superman: Australian Aboriginal people, mediated publicness and the culture of sharing on the Internet, Anthrovision [En ligne] 1 (1), $21 \mathrm{p}$. (http://anthrovision.revues.org/362; DOI : 10.4000/anthrovision.362).

DE LARGY HEALY Jessica, 2016. Archives sonores et médiation de l'ancestral dans le film Two Brothers at Galarra (Terre d'Arnhem, Australie), Gradhiva 24, pp. 51-81.

DE LARGY HEALY Jessica, 2017. Retours sur images. Nouveaux médias et transmission du secret dans les rituels du nord de l'Australie, ethnographiques.org [En ligne] 33, 32 p. (http://

www.ethnographiques.org/2016/De-Largy-Healy).

DE LARGY HEALY Jessica et Barbara GLOWCZEWSKI, 2014. Valeurs et réappropriations patrimoniales, des musées à la Toile: exemples australiens et polynésiens, in L. Dousset, M. Salaün \& B. Glowczewski (éds), Les sciences humaines et sociales dans le Pacifique Sud, Marseille, PacifiqueCREDO publications, pp. 183-205. 
DELPUECH André, Christine LAURIÈRE et Carine PELTIER-CAROFF (éds), 2017. Les années folles de l'ethnographie. Trocadéro 28-37, Paris, publications scientifiques du Muséum national d'histoire naturelle.

DIAWARA Manthia, 1992. African Cinema. Culture and Politics, Bloomington, Indiana University Press.

DUNLOP Ian, 1979. Ethnographic film-making in Australia : the first seventy years (1898-1968), Aboriginal History 3, pp. 111-119.

DWYER Rachel, 2006. Filming Gods. Religion and Indian Cinema, London, Routledge, 2006.

EDWARDS Elizabeth, 1998. Performing science: still photography and the Torres Strait expedition, in S. Rouse et A. Herle (eds), Cambridge and the Torres Strait: centenary essays on the 1898 Anthropological Expedition, Cambridge, Cambridge University Press, pp. 106-135.

FAURIE Mathias et Mélissa NAYRAL, 2012. L'Ordre et la morale : Quand l'industrie du cinéma bouscule la coutume kanak, Journal de la Société des Océanistes 134, pp. 121-136 (https://

journals.openedition.org/jso/6641).

FEIGELSON Kristian et Monique DAGNAUd (éds), 2012. Bollywood : industrie des images, Paris, Presses Sorbonne Nouvelle.

FERRO Marc, 1993. Cinéma et histoire, Paris, Gallimard.

FLAHERTY Frances, 1970. Préface, in Premier catalogue sélectif international de films ethnographiques sur la région du Pacifique, Paris, UNESCO publications (http://unesdoc.unesco.org/images/ 0000/000031/003117fb.pdf).

GANDIN Eliane, 1998. Le voyage dans le Pacifique de Bougainville à Giraudoux, Paris, L'Harmattan. GINSBURG Faye, 2002. Screen memories: resignifying the traditional in Indigenous Media, in F. Ginsburg, L. Abu-Lughod \& B. Larkin (eds), Media worlds: anthropology on new terrain, London, Berkeley, University of California Press, pp. 39-57.

GINSBURG Faye, 2005. The Parallax Effect: the Impact of Aboriginal Media on Ethnographic Film, Visual Anthropology Review 11 (2), pp. 64-76 (DOI : 10.1525/var.1995.11.2.64).

GLOWCZEWSKI Barbara, 2014. Beyond the frames of film and Aboriginal fieldwork, in C. Pasqualino et A. Schneider (eds), Experimental film and Anthropology, London, Bloomsbury Books, pp. 147-164. GOERG Odile, 2015. Fantômas sous les tropiques : aller au cinéma en Afrique coloniale, Paris, Vendémiaire.

GRIFFITHS Alison, 1997. Knowledge and Visuality in Turn of the Century Anthropology : the Early Ethnographic Cinema of Alfred Cort Haddon and Walter Baldwin Spencer, Visual Anthropology Review 12 (2), pp. 18-43 (DOI : 10.1525/var.1996.12.2.18).

GRIFFITHS Alison, 2002. Wondrous Difference. Cinema, Anthropology, and Turn-of-the-Century Visual Culture, New York, Columbia University Press.

HAU'OFA 'Epeli, 1994. Our Sea of Islands, The Contemporary Pacific 6 (1), pp. 147-161. (trad.

française : Notre mer d'îles, Papeete, Pacific Islanders editions, 2013).

HENRY Rosita and Daniela VÁVROVÁ, 2016. An Extraordinary Wedding: Some reflections on the ethics and aesthetics of authorial strategies in ethnographic filmmaking, Anthrovision 4 (1), $20 \mathrm{p}$. (http://journals.openedition.org/anthrovision/2237). 
HINKSON Melinda, 2002. New Media Projects at Yuendumu: inter-cultural engagement and selfdetermination in an era of accelerated globalization, Continuum: Journal of Media \& Cultural Studies 16 (2), pp. 201-220 (DOI : 10.1080/10304310220138769).

JACKSON Moana, 2009. Once Were Gardners. On the scientific method and the "warrior gene" [keynote address at 2009 Cutting Edge conference discusses research done on Maori], New Zealand Drug Foundation, vidéo de 9 min 54 s. (https://www.youtube.com/watch? v=HfAe3Zvgui4).

JOLLY Margaret, 1997. White Shadows in the Darkness : representations of Polynesian women in early cinema, Pacific Studies 20 (4), pp. 125-150 (DOI : 10.1353/cp.2007.0054).

JOLLY Margaret, 2007. Imagining Oceania: indigenous and foreign representations of a sea of islands, Contemporary Pacific 19 (2), pp. 508-545.

JORDAN Pierre-Léonce, 1992. Cinéma $=$ Cinema $=$ Kino, Paris, Ramsay-La Villette

KABUTAULAKA Tarcisius, 2015. Re-Presenting Melanesia: Ignoble Savages and Melanesian AlterNatives, The Contemporary Pacific 27 (1), pp. 110-146 (DOI : 10.1353/cp.2015.0027).

KIHARA Shigeyuki, 2008. Kihara: Living photographs, série de photographies et de cartes postales (https://www.metmuseum.org/exhibitions/listings/2008/shigeyuki-kihara).

KIRSTEN Sven A., 2014. Tiki Pop, Köln, Taschen Verlag.

LAFERTÉ Gilles, 2017. Le film ethnographique comme archives. L'œuvre de Jean-Dominique Lajoux, Études rurales 199, pp. 15-32.

LANDMAN Jane et Chris Ballard, 2010. An Ocean of Images. Film and History in the Pacific, The Journal of Pacific History 45 (1), pp. 1-20.

LANGTON Marcia, 1993. 'Well I heard it on the Radio and I saw it on the Television...': An essay for the Australian Film Commission on the Politics and Aesthetics of Filmmaking by and about Aboriginal People and Things, Sydney, Australian Film Commission.

LARKIN Brian, 2008. Signal and Noise. Media, Infrastructure, and Urban Culture in Nigeria, Durham, Duke University Press.

LAROCHE Marie-Charlotte, 1966. Films d'information et documentaires scientifiques réalisés par des cinéastes français dans la région du Pacifique sud, rapport de la Société des Océanistes à l'UNESCO (https://unesdoc.unesco.org/ark:/48223/pf0000143812fre).

LEBLIC Isabelle, 2012. Le film de Mathieu Kassovitz, L'Ordre et la morale. Quand la fiction se confronte à la réalité, Journal de la Société des Océanistes 134, pp. 111-120 (https:// journals.openedition.org/jso/6640 ; DOI : 10.4000/jso.6640).

LELIÈVRE Samuel, 2013. Les cinémas africains dans l'histoire. D'une historiographie (éthique) à venir, 1895. Mille huit cent quatre-vingt-quinze [En ligne] 69, pp. 136-147 (http:// journals.openedition.org/1895/4614; DOI : 10.4000/1895.4614). LINDSTROM Lamont, 2016. Shooting Melanesians: Martin Johnson and Edward Salisbury in the Southwest Pacific, Visual Anthropology 29 (4-5), pp. 360-381 (DOI : 10.1080/08949468.2016.1191929). LOUVAT Marc Emmanuel, 2017. Petite histoire du cinéma en Polynésie française : Cinematamua, Paris, L'Harmattan.

MACDOUGALl David, 1991. Whose Story Is It?, Visual Anthropology Review 7 (2), pp. 2-10 (DOI : 10.1525/var.1991.7.2.2). 
MACDOUGALl David, 1995. Subtitling Ethnographic Films: Archetypes into Individualities, Visual Anthropology Review 11 (1), pp. 83-91 (DOI : 10.1525/var.1995.11.1.83).

MACDOUGALL David, 2004. L'anthropologie visuelle et les chemins du savoir, Journal des anthropologues 98-99, pp. 279-233.

MALTHÊTE Jacques, 1990. Biographie de Gaston Méliès, 1895, Revue d'histoire du cinéma 7, pp. 85-90.

MARTENS, Emiel, 2012. Maori on the Silver Screen, International Journal of Critical Indigenous Studies. MAWYER Alexander, 1998. From photons to electrons: the film guide Moving Images of the Pacific Islands, Contemporary Pacific 10 (2), pp. 457-465.

MELLON James, 1994. Representations of Micronesia on film, video and television, East-West Film Journal 8 (1), pp. 86-120.

MERLE Isabelle, 1998. Le Mabo case. L'Australie face à son passé colonial, Genèses 53 (2), pp. 209-229 (DOI : 10.3406/ahess.1998.279661).

MICHAELS Eric, 1986. The Aboriginal Invention of Television in Central Australia 1982-1986, Canberra, Australian Institute of Aboriginal Studies.

MICHAELS Eric, 1994. Bad Aboriginal Art: Tradition, Media and Technological Horizons, St Leonards NSW, Allen \& Unwin.

MICHAELS Eric et Francis KELLY, 1984. The social organisation of an Aboriginal video workplace, Australian Aboriginal Studies 1, pp. 26-34.

MORPHY Howard, 2012. Becoming a Visual Anthropologist, Humanities Research 18 (1), pp. 5-20 (DOI : 10.22459/HR.XVIII.01.2012.01).

NELSON Hank, 1992. Write history: reel history, in B. Lal (ed.), Pacific Islands History: journeys and transformations, Canberra, Pacific Islands History, pp. 184-202.

NGATA Tina, 2018 (19 déc.). Once were gardeners, lovers, poets... and warriors, The Spinoff [New Zealand online magazine] (https://thespinoff.co.nz/atea/19-12-2018/once-were-gardeners-loversand-poets-not-warriors/).

NOIRIEL Gérard, 2003. Penser avec, penser contre. Itinéraire d'un historien, Paris, Éditions Belin. O'REILLY Patrick, 1949. Le « documentaire » ethnographique en Océanie, Journal de la Société des Océanistes 5, pp. 117-144 (https://www.persee.fr/doc/jso0300-953x1949num551630).

PATRICK Rhianna, 2018. The Cambridge Anthropological Expedition to the Torres Strait (1898), Curator's notes (https://aso.gov.au/titles/music/1898-torres-strait-recordings/notes/).

PAULET Jean-Pierre, 2002. Les représentations mentales en géographie, Paris, Anthropos. POUILLON François et Jean-Claude VATIN, 2011. Après l'Orientalisme : l'Orient créé par l'Orient, Paris, IISM, éd. Karthala.

RAHEJA Michelle, 2007. Reading Nanook's Smile: Visual Sovereignty, Indigenous Revisions of Ethnography, and Atanarjuat (The Fast Runner), American Quarterly 59 (4), pp. 1159-1185 (DOI : 10.1353/aq.2007.0083).

REYES Luis, 1995. Made in Paradise: Hollywood's films of Hawai'i and the South Seas, Honolulu, Mutual Pub.

ROUCH Jean, 1967 [1961]. Situation et tendance du cinéma en Afrique, in Premier catalogue sélectif international de films ethnographiques sur l'Afrique noire, Paris, UNESCO, pp. 374-408. 
ROUCH Jean, 1970. Avant-propos, in Premier catalogue sélectif international de films ethnographiques sur la région du Pacifique, Paris, UNESCO publications, pp. 13-16 (http://unesdoc.unesco.org/images/ 0000/000031/003117fb.pdf).

ROUCH Jean, 2009. Cinéma et anthropologie (textes réunis par J.-P. Colleyn), Paris, Cahiers du Cinéma. Rousso Henry, 1987. Le syndrome de Vichy (1944-198..), Paris, Le Seuil.

SCREEN AUSTRALIA, 2010. The Black List, a catalogue of film AND TV projects since 1970 with Indigenous Australians in key creative roles, Sydney, Screen Australia (https://www.screenaustralia.gov.au/ getmedia/a321de20-911c-448b-8afa-f29bc82f16e6/Black-list.pdf).

SMITH Bernard, 1985. European Vision and the South Pacific, Sydney, Harper \& Row (DOI : 10.2307/750143).

SMITH Linda Tuhiwai, 1999. Decolonizing Methodologies. Research and Indigenous Peoples, Londres et Dunedin, Zed Books et University of Otago Press.

SMYTH Rosaleen, 1992. Reel Pacific history: the Pacific Islands on film, video and television, in B. Lal (ed.), Pacific Islands History: journeys and transformations, Canberra, Pacific Islands History, pp. 203-224.

SPENCER Baldwin and Francis James GILLEN, 1899. Native Tribes of Central Australia, London, New York, Macmillan and Co (DOI : 10.2307/2842887).

STASZAK Jean-François, 2003. Carte mentale, in J. Lévy, M. Lussault (éds), Dictionnaire de la géographie et de l'espace des sociétés, Paris, Belin, pp. 132-133.

STOLER Ann, 2009. Along the Archival Grain. Epistemic Anxieties and Colonial Common Sense, Princeton, Princeton University Press.

TAOUMA Lisa, 2004. Gauguin is dead ... there is no paradise, Journal of Intercultural Studies 25 (1), pp. 35-46 (DOI : 10.1080/07256860410001687009).

TEAIwA Teresa, 1994. Bikinis and other S/Pacific N/Oceans, The Contemporary Pacific 6 (1), pp. 87-109.

TENGAN Ty, 2008. Native men remade: Gender and Nation in Contemporary Hawai', Durham, Duke University Press.

THOMAS Nicholas, 1997. In Oceania: Visions, Artifacts, Histories, Durham, Duke University Press. THOMAS Nicholas, 2010. Islanders, The Pacific in the Age of Empire, New Haven, Yale University Press. UNESCO, 1967. Premier catalogue sélectif international de films ethnographiques sur l'Afrique noire, Paris, UNESCO.

VIEYRA Soumanou Paulin, 1975. Le cinéma africain, des origines à nos jours, Paris, Présence africaine. WITTERSHEIM Eric, 1999. Les chemins de l'authenticité. Les anthropologues et la renaissance mélanésienne, L'Homme 151, pp. 181-206 (DOI : 10.3406/hom.1999.453625).

ZÉAU Caroline, 2008. Cinéaste ou propagandiste ? John Grierson et « l'idée documentaire », 1895. Mille huit cent quatre-vingt-quinze [En ligne], 55, pp. 52-74 (http://journals.openedition.org/ 1895/4104).

\section{Filmography}

BALSHOFER Fred J., 1911. An Indian Love Story, USA, short film (unknown length). 
BORGEAUD Belle and Adam ROBINSON, 2009. Meet the Natives, USA, Keo Films, 5 x 50 min (http:// www.keofilms.com/projects/meet-the-natives/).

BRETON Stéphane, 2001. Eux et moi/Them and me, France, Les Films d'Ici, 63 min.

CARO Niki, 2002. Paï / Whale Rider, New Zealand and Germany, 101 min.

COLE Beck, Craig ANDERSON and Erica GLYNN, 2014-2018. Black Comedy, series, Australia, Scarlett Pictures Pty Limited/Australian Broadcasting Production, 3 seasons, 18 x 30 min.

CONNOLLY Bob and Robin ANDERSON, 1983, 1989 and 1992. The Highland Trilogy [First Contact, Joe Leahy's Neighbours and Black Harvest], Australia/Papua New Guinea, 58+90+90 min.

DAGNEAU Gilles, 2008. Le gendarme Citron. Une aventure cinématographique en Nouvelle-Calédonie, France, AAA productions, $52 \mathrm{~min}$.

DEAN Bentley and Martin BUTLER, 2015. Tanna, Australia, Vanuatu, 104 min.

DIAMOND Neil, Catherine BAINBRIDGE andet Jeremiah HAYES, 2009. Real Injuns, Canada, 85 min.

DOZIER Marc and Jean-Marie BARRÈRE, 2007. L'exploration inversée : le tour de France de deux Papous, France, Bonne Pioche Production, 101 min.

DUNLOP Ian, 2007. Yirrkala Film Project, 18 DVDs, Sydney, Film Australia.

FER Yannick and Gwendoline MALOGNE-FER, 2010. Pain ou coco. Moorea ou les deux traditions, Wapiti Production, France-Télévision/RFo Polynésie, Canal Overseas Production, 63 min (https:// vimeo.com/104943192).

FLAHERTY Robert, 1922. Nanook of the North, USA/France, $78 \mathrm{~min}$.

FLAHERTY Robert, 1925. Moana, The Love Life of a South Sea Siren, USA, 77 min.

FORD John, 1939. Stagecoach, USA, $97 \mathrm{~min}$.

FORD John, 1964. Cheyenne Autumn, USA, 154 min.

GRIFFEN Ryan, Jon BELL, Jonathan GAVIN et al., 2016-2017. Cleverman, series, New Zealand, 2 seasons, $12 \times 50$ min.

HADDON Alfred Cort, c. 1898. Torres Strait Islanders, Australia, 3 black and white films (1 min $3 \mathrm{~s}, 40 \mathrm{~s}$ and $1 \mathrm{~min} 15 \mathrm{~s}$ ) (https://aso.gov.au/titles/historical/torres-strait-islanders/clip1/).

HERENIKO Vilsoni, 2004. Pear Ta Ma 'On Maf: The Land Has Eyes, USA/Fiji, 87 min.

HURLEY Frank, 1921. Pearls and Savages, Australia, 56 min.

IMAG'IN PRODUCTIONS, 2008-... Chez Nadette, series, France [Nouvelle-Calédonie], 2 seasons, $160 \mathrm{x}$ $3 \mathrm{~min}$.

ITEANU André andet Eytan KAPON, 2009. Reviens Demain, France, 70 min.

KASSOVITZ Matthieu, 2011. Rebellion / L'Ordre et la morale, France, 136 min.

MALICK Terence, 1998. The Thin Red Line, USA, $170 \mathrm{~min}$.

MÉLIÈs Georges, 1902. A Trip to the Moon / Le voyage dans la lune, France, 74 min.

MÉLIÈs Gaston, 1912, A Tale of Old Tahiti, USA, short film, black and white, silent.

MILLET Raphaël, 2014. Le voyage cinématographique de Gaston Méliès à Tahiti, France, Nocturnes

Productions et France Télévision, 51 min. 
MILLET Raphaël, 2015. Le voyage cinématographique de Gaston Méliès dans les mers du Sud et en ExtrêmeOrient, France, Nocturnes Productions et Polynésie $1^{\mathrm{e}}, 60 \mathrm{~min}$.

MITCHELL Elizabeth, 2004-2009. Bro'Town, series, New Zealand, 5 seasons, 32 x 22 min.

MURNAU Friedrich Wilhelm, 1922. Nosferatu the Vampire, Germany, 92 min.

MURNAU Friedrich Wilhelm, 1927. Sunrise, USA, 95 min.

O’REILLY Patrick, 1935. Bougainville, Solomon Islands, 36 min.

o'RoURKE Dennis, 1988, Cannibal Tours, Australia, CameraWork, 72 min.

PARSONS Charlie, 2007-2009. Meet the Natives: England and USA, reality series, Travel Channel, UK/USA, 2 seasons ( $3+6 \times 45 \mathrm{~min})$.

PERKINS Rachel et al., 2012-2015. Redfern Now, series, Australia, Blackfella Films, 2 seasons (6 x $52 \mathrm{~min})$.

PERKINS Rachel et al., 2008. First Australians, Australia, Blackefella Films, 1 x 70 min and 6 x 52 min. PIKE Andrew, Hank NELSON and Gavan DAWS, 1982. Angels of War, Australia, Ronin Films, 52 min. QUINTON Hita, Kiel MCNAUGHTON and Hanelle HARRIS, 2017. Ahikāroa, web series, New Zealand, 2 seasons, 14 x 26 min (https://www.ahikaroa.nz).

REIHANA Lisa, 2015-17. In the Pursuit of Venus [Infected], video, 2 min 38 s (https://vimeo.com/ 233491752).

SPENCER Baldwin, 1901. Rain Ceremony, Australia (http://spencerandgillen.net/objects/ 4fac6ade023fd704f475bf23).

STANDRING Glenn, 2019-... The Dead lands, New-Zealand, 8 episodes.

TAMAHORI Lee, 1994. Once were warriors, New Zealand, $102 \mathrm{~min}$.

TAMAHORI Lee, 2002. Die Another Day, USA, 134 min.

TAITUSI Anthony, 2016-... Foha Tau, series, Wallis and Futuna, Kalala Magne, 3 x 30 min.

TAULAPAPA McMullin Dan, 2016. 100 Tikis. An Appropriation Video, 43 min 13 s.

TAUROG Norman (dir.), 1961. Blue Hawaii, produced by Hal B. Wallis, screenplay by Hal Kanter, Hollywood CA, Paramount Pictures, $102 \mathrm{~min}$.

TEFAATAU Marie-Eve and Yves Edouard MALAKAI, 2017-... Maui et Coco, series, France, Vitalis, $60 \mathrm{x}$ $4 \mathrm{~min}$.

THORNTON Warwick, 2009. Samson \& Delilah, Australia, $101 \mathrm{~min}$.

VAIAOGA-Ioasa Stallone, 2016. Three Wise Cousins, New Zealand/ Samoa, $89 \mathrm{~min}$.

WAN James, 2018. Aquaman, DC Entertainment, Warner Bros, USA, 148 min.

WAN SMOLBAG Theater, 2007-... Love Patrol, series, Vanuatu, 7 seasons, 80 episodes.

WITTERSHEIM Eric, 2003. Grassroots, Those Who Vote, 85 min (Philux DVD, 2007 https:// www.youtube.com/watch?v=RXRHBPPFjw).

WITTERSHEIM Eric, 2009. The Poet' Salary, France, Blacksand Association - CNRS, 59 min (DVD: Écouter le monde, La Huit productions - web: https://www.youtube.com/watch?v=fawBBjP0PYo). 
WITTERSHEIM Eric and Cécile KIELAR, 2011. Man Vila, Fonds Pacifique - East-West Center - Blacksand Association, 17 min (https://www.youtube.com/watch?v=hfNbet-vSrY).

\section{NOTES}

1. These thoughts were developed during a series of presentations and discussions: the EHESS $e^{-}$ Toile Pacifique conference (2013); the EHESS Formation à la recherche dans l'aire océanienne seminar (2016-17); as part of a course at the University of French Polynesia (2015); at screenings of Eric Wittersheim films; and at screenings of "Cinéma des Océanistes" at the Musée du quai Branly Jacques Chirac run by Jessica De Largy Healy and Aurélie Condevaux. Our thanks to all the participants and organisers involved in these events, and to Jean-Paul Colleyn and Marie Salaün who reviewed a first draft of this text. Translated from French by Dominic Horsfall with funding from the Laboratoire d'ethnologie et de sociologie comparative (LESC, UPN-CNRS).

2. Among them, the works of Vieyra, 1975; Rouch, 1967 [1961] and 2009; Larkin, 2008; Diawara, 1992; Boukary, 2019; Benali, 1998; Goerg, 2015. For an indicative bibliography on African cinema, see Lelièvre (2013: 140), as well as a volume compiled by Alessandro Jedlowski on African audiovisual media and global capitalism, to be published in Politique africaine. For Indian cinema and the Bollywood phenomenon, see Dwyer, 2006; Bhattacharya, Metha \& Pandharipande, 2010; Feigelson \& Dagnaud, 2012.

3. As shown by the controversies surrounding Disney's Moana (2016), widely reported in the media, including in the New York Times.

4. In the sense of cinéma d'auteur, a notion first developed by the critic André Bazin (1918-1958) that places the director's vision and artistic personality at the heart of the filmmaking process; it would become popular during the New Wave that started in the 1960s (Bazin, 1967).

5. As seen in Remembering Yayayi (Myers, Dunlop \& Devenson, 2014), Lajamanu (Glowczewski, 2018), or Le Gendarme Citron (Dagneau, 2008; see also Soriano, this volume).

6. The discovery of Papuan groups in the New Guinea highlands in 1926 serves as the starting point for Bob Connolly and Robin Anderson's documentary trilogy.

7. This extraordinary expedition is depicted in Raphaël Millet's two films, Le voyage cinématographique de Gaston Méliès à Tahiti (2014) and Le voyage cinématographique de Gaston Méliès dans les mers du Sud et en Extrême-Orient (2015).

8. Friedrich Wilhelm Murnau (1888-1931), a German expressionist filmmaker. His most notable works include Nosferatu (1922) and Sunrise (1927), the latter winning Best Picture at the 1927 Academy Awards.

9. Three clips from Torres Strait Islanders (c. 1898) can be viewed on the National Film and Sound Archive's website (https://aso.gov.au/titles/historical/torres-strait-islanders/clip1/).

10. The "Mabo Case" (1992), named after its most prominent advocate (Eddie Koiki Mabo, 1936-1992), recognised for the first time the existence of Indigenous land rights (native title) in Australia, invalidating the legal fiction that had prevailed until then of terra nullius (Merle, 1998). 11. In 1909, philanthropist Albert Kahn and geographer Jean Brunhes launched a project of photographic and cinematographic documentation across sixty countries (1909-1931). The films from Archives of the Planet are now held in the Albert Kahn departmental museum in BoulogneBillancourt.

12. Later succeeded by the Musée de l'Homme from 1937.

13. Bougainville only became part of Papua New Guinea in 1975 following the latter's independence, a move that triggered a long armed conflict. In December 2019, the inhabitants of Bougainville voted widely in favour of independence from Papua New Guinea.

14. Our thanks to CNRS Images for their kind permission to reproduce this still. 
15. Another catalogue raisonné of films and videos on the Pacific Island region was published in 1994 by the University of Hawai'i's Center for Pacific Islands Studies, a seminal work in the dialogue between the arts and sciences (Aoki, 1994).

16. Initially commissioned by the Commonwealth Film Unit to record the impact of a local mine on the inhabitants of Yirrkala mission in north-eastern Arnhem Land, Ian Dunlop established a long-running collaboration with the Yolngu, eventually producing with them, from 1979 to 1996, a series of twenty-two films.

17. Or indeed "authority", in both the literal and figurative sense.

18. For a French example of a documentary with a reversed perspective, see Dozier \& Barrère, 2007.

19. For examples of Aboriginal Australian shows in a range of genres: drama: Redfern Now (2012-2015, R. Perkins et al.; see the series review by Vanessa Castejon in this volume); historical: First Australians (2008, R. Perkins et al.); science fiction: Cleverman (2016-2017, R. Griffen et al.); comedy: Black Comedy (2014, B. Cole et al.). For New Zealand: bilingual web series Ahikāroa (2017, H. Quinton et al.); Samoan comedy series Bro'Town (2004-2009, E. Mitchell); for Vanuatu: Love Patrol (2007-present), produced by Wan smol bag Theatre. Rarer examples from the Frenchspeaking regions of the Pacific: Wallisian trilogy Foha Tau (2016, A. Taitusi); Polynesian comedy Maui et Coco (2017, M.-E. Tefaatau and Y.E. Malakai); and "shortcom" Chez Nadette (160 episodes since 2008, Imag'in Productions) featuring characters from well-known New Caledonian comic book La Brousse en folie by Bernard Berger.

20. Who later found success in Hollywood, directing the James Bond film Die Another Day (2002).

21. Like the extremely violent The Dead Lands (2019, Glenn Standring), a series adapted from the eponymous film by Toa Fraser (2014) that takes place in pre-colonial Maori society.

22. See also Maori academic Tina Ngata's critique (2018), particularly with regard to remarks made by actor Jason Momoa, star of Hollywood blockbuster Aquaman (2018, J. Wan).

23. This question of authenticity generated much debate in Pacific studies during the 1980 and 1990s, with notable contributions from James Clifford, Jonathan Friedman, Margaret Jolly, and Roger Keesing (cf. Wittersheim, 1999).

24. As Jacob Kapere once said of the "threat" posed by the arrival of the DVD, "VHS i strong yet!". Before his sudden death in early 2017, Jacob Kapere was a key player in expanding the Vanuatu Cultural Centre's film archives over thirty years, while directing and shooting numerous documentaries on kastom himself. A native of Tanna, he also served as traditional chief for the members of his community living in the capital Port Vila. Margaret Jolly and Marc Tabani both dedicate their articles to his memory.

25. Former director of the Maison de la culture in Tahiti, now Minister of Culture in French Polynesia.

26. There is considerable literature on the subject of Aboriginal and Maori cinematography, too much to explore in sufficient detail here (see in particular: Screen Australia, 2010; Martens, 2012).

\section{AUTHORS}

\section{JESSICA DE LARGY HEALY}

CNRS, Laboratoire d'ethnologie et de sociologie comparative, jessica.delargyhealy@cnrs.fr 


\section{ERIC WITTERSHEIM}

EHESS, Institut de recherche interdisciplinaire sur les enjeux sociaux, eric.wittersheim@ehess.fr 